\title{
Character investigation and homology, with a brief discussion on the phylogenetic relationships of Annelida and Polychaeta within Metazoa
}

\section{José Eriberto De Assis ${ }^{1, *}$ and Martin Lindsey Christoffersen $^{2}$}

\begin{abstract}
${ }^{1}$ Prefeitura Municipal de Bayeux. Departamento de Educação. Rua Santa Tereza, S/No. Sesi. Bayeux-PB, Brazil (CEP 58306-060).Email: eri.assis@gmail.com

${ }^{2}$ Universidade Federal da Paraíba. Centro de Ciências Exatas e da Natureza. Departamento de Sistemática e Ecologia. João Pessoa-PB, Brazil (CEP 58051-900).
\end{abstract}

\begin{abstract}
The intense production of information demands coherent treatment of available bodies of theoretical knowledge. A critical revision of methods in use within research programs is essential to maintain an adequate ontology and to guarantee the particular epistemological position required by each research area. The theory of Phylogenetic Systematics was developed in multiple forms, resulting in hypotheses that may be widely incongruent. This reflects the crisis of present paradigm, and illustrates failures in present phylogenetic thinking. The aim of the study is to discuss characters and homology hypotheses based on Hennigian principles. We present samples from the most unresolved groups within the evolutionary history of the Metazoa: Annelida and Polychaeta. The main phylogenetic proposals appearing in the history of the Annelida, from morphological (living and fossilized organisms) to molecular approaches are discussed. We do not consider annelids and polychaetes to be monophyletic entities. Both taxa need more detailed comparisons with others groups, such as deuterostomes. According to our published opinions, Annelida and Polychaeta are placed at the base of the deuterostomes, and these worm-like organisms are ultimately the ancestors of the Enterocoela. Thus, in order to systematize the Metameria, we have regarded Annelida, Pleistoannelida, Lophotrochozoa and Protostomia as being paraphyletic taxa.
\end{abstract}

Keywords: Phylogenetic principles; Annelids; Synapomorphies; Morphology; Molecular Systematics.
Received

June 19, 2020

Accepted

August 22, 2020

Released August 31, 2020

Full Text Article

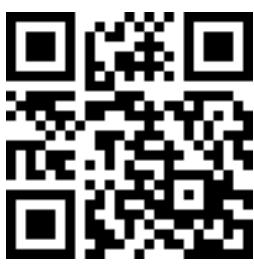

ORCID

(D) $0000-0002-1522-2904$ José Eriberto De Assis

D) 0000-0001-8108-1938

Martin Lindsey

Christoffersen

\section{Introduction}

Characters and hypotheses of homology have been the subject of many definitions and are central to the development of phylogenetic systematics (Laubichler, 2000; 
Wagner, 2001; Brooks and McLennan, 2002; De Pinna, 1991; Wiley and Lieberman, 2011; Assis, 2012; Nixon and Carpenter, 2012; Williams and Ebach, 2012; Brower and De Pinna, 2012). We present a view on characters and homology, based on the system of the Annelida and Polychaeta. Attempts at the systematization of these taxa are mainly the results of morphological data (Rouse and Fauchald 1995, 1997; Almeida et al., 2003), and recently, of inputs from molecules (Colgan et al., 2006; Rousset et al., 2007; Struck et al., 2011; Weigert et al., 2014). Our outlook has caused much repercussion on the systematics of annelids and on the phylogeny of the Metazoa.

In order to identify in which epistemological context this situation occurs, it becomes essential to consider laws and theories within the natural sciences and, more specifically, within biology. Theoretical bodies are considered by scientists as representatives of a genuine theory, depending on the conceptualization of the theory or on the adopted law. Some influential positions (Hempel, 1948) consider that only natural laws legitimate theoretical bodies, while other conceptions admit broader degrees of axiomatic subjectivity, as a consequence of the plasticity inherent in the concept of "laws" as applied to the diversity of known natural phenomena (Dretske, 1977). The classical conceptualization of theory was based on the physico-mathematical model, adopted since the beginning of the scientific revolution, a theory becomes a set of statements organized deductively or axiomatically (Carnap, 1956). Yet, as considered by Beaty (1993), how concrete these theories or laws become, is a subject of discord even in physics, in the conception of cosmological contingency, for example. According to Martínez (2011), this conception establishes itself as a general metatheory, rather than being restricted to a single area of science, applying to any program of natural investigation. Paradoxically, this concept, that is not well supported, even within physics, originated proposals of axiomatization in several specific theories in the area of biology. Hennig (1966: 3) also tried to provide meaning for biology in terms of the laws of physics:

\begin{abstract}
If we arbitrarily designate only physical laws as "laws" in natural science, then we can agree that biology is a science of laws, a nomothetic science, insofar as it tries to analyze the stationary processes in their sharply individualized forms, in terms of physical regularities, and seeks to analyze causally the broad range of the processes of change in form.
\end{abstract}

Hennig (1966) then defines biology as "a systematic science of ordering, in that it seeks to include the tremendous variety of individual organic forms in an ordered system".

Under this scenario, the importance of placing Phylogenetic Systematics within the natural sciences becomes explicit. As a science, Phylogenetic Systematics aims to describe the objects of scientific investigation and to establish theories and general laws, in order to explain, and perhaps predict, particular ev events (Hempel, 1965). As phrased by Hennig (1966: 2), "the peculiar place and significance of systematics in biology is clearly recognizable only if an account of the place of biology itself among the natural sciences is first presented". The objects that systematics aims to explain, the existence or relationships of which are sought, are natural groups. The analysis of characters of organisms structure relationships among groups that inherited these characters. In the light of our knowledge on evolutionary biology, explanatory hypotheses are generated homologies, transformation series, cladograms (Fitzhugh, 2009). As indicated by Hennig, “'order' and 'systematics' in this sense, are not equivalent to description, but also include explanation and rationalization". Phylogenetic Systematics is thus a scientific program, because it presents natural criteria for the ordination of diversity in biological systems. This ordination proceeds by analyzing the multidimensionality of characters present in semaphoront (temporal samples within the life cycles of an individual). Biological evolution justifies the procedures in a transtemporal dimension. The historical aspect of 
the phylogenetic system permits direct extensions into diverse other systems that may belong in systematic biology. For this reason, Phylogenetic Systematics must represent the general reference system for biology.

The phylogenetic method proposed by Hennig (1966), which revolutionized the history of comparative biology, establishes genealogical relationships among species based on homologous characters, named synapomorphies. After this proposition, many authors contributed to the development of phylogenetic methods, enhancing our comprehension of the evolutionary history of organisms. With the method of parsimony analysis, it has been possible to quantify information and detect characters responsible for incongruences in multiple phylogenetic trees (Farris, 1969, 1970; Kluge and Farris, 1969; Goloboff, 1996; Carpenter, 1988; Goloboff et al., 2008). The best procedures for selecting outgroups for comparisons with the studied ingroup have been devised (Mickevich, 1982; Donoghue and Cantino, 1984; Brooks and Wiley, 1985; de Queiroz 1985; Kluge and Strauss, 1985; Nelson, 1985; Clark and Curran, 1986; O'Grady and Deets, 1987; Mickevich and Lipscomb, 1991; Nixon and Carpenter, 1993; Grandcolas et al., 2005). Methods for coding and polarizing binary and multistate characters have been produced (Nelson and Platnick, 1982; Mickevich and Lipscomb, 1991; Wilkinson, 1995; Fitzhugh, 2006; Zeppelini, 2001, 2011). Recently, molecular characters have dominated the scene (Nixon and Carpenter, 2011), reflecting what we may interpret as the gradual establishment of the present scientific paradigm (Kuhn, 1970). This position now represents the standardized methodological model followed by the more important periodicals publishing scientific papers in this research area. To deviate from this program implies confronting established monopolies and defying the gatekeepers of science, the peer reviewers.

The phylogenetic method (Hennig, 1966) unites natural groups (monophyletic taxa), are based on shared evolutionary novelties (synapomorphies), corresponding to a series of procedures deduced from the empirical knowledge of evolution (Wiley, 1981; de Pinna, 1991; Amorim, 2002; Wiley and Lieberman, 2011). Starting in the 1960s, a series of computational methods began to appear, originating especially from the papers of Kluge and Farris (1969) and Farris $(1969,1970)$, that furnished more rigorous methodological procedures for the reconstruction of phylogenetic trees. The main aim of tree reconstruction became the resolution of incongruence and the search for the single most parsimonious tree (Amorim, 2002).

This change in the argumentative structure of phylogenetic analyses follows a general tendency in theoretical biology to incorporate a statistical philosophy (Pigliucci, 2012). This stance only becomes problematical when it obfuscates other crucial points inherent in phylogenetic methods, which must be explicit in the analysis (Hennig 1966). These methods are fundamental for the structuring of the hypothesis in question. They become responsible for making the specific proposal open to testing and discussion by others, which characterizes the scientific debate. Theoretical pluralism, in which "different items of a same domain necessitate explanations in terms of different theories or mechanisms" (Beatty, 1995), is characteristic of biology. This is in opposition to the theoretical monism of the Newtonian tradition, which attempts to explain, in a reductionist form, a domain of phenomena with as few mechanisms as possible, and, in the best possible case, with a single mechanism (Martine, 2011). The standardization of the structure of phylogenetic analyses under a statistical bias, as well as corroborating the establishment of the dominant paradigm (Kuhn, 1970), reflects the methodological reductionism in which the statistical entities are considered more relevant for the development of theories in biology (Pigliucci, 2012). Phylogenetic analyses have likewise become subject to this statistical bias and reductionist stance. Such an outlook leads to conflicts with the qualitative method established by the Hennigian School. This tendency must be taken with caution. It is sensible to take into account the limitations of each 
method in practice, to avoid reckless proposals, and in order to produce that are more richly structured hypothesis from a theoretical point of view (Fang and Casadevall, 2011).

The definition of characters and their states have been widely discussed in the literature (Nelson and Platnick, 1981; Wiley, 1981; Platnick, 1982; Pimentel and Riggins, 1987; Farris, 1970; Wagner, 2001; Amorim, 2002; Brooks and McLennan, 2002; Zeppelini, 2011). This discussion on the importance of the concept of a character and the choice of coding methods appears to have ended, particularly in phylogenetic reconstruction based on molecular data, where data are not further investigated, after quantification procedures. Genetic sequences permit the grouping by sites of genetic similarity. This is considered by some authors to represent "ontogenetic similarity" (Nixon and Carpenter, 2011). Differences in character concepts introduce an additional level of ambiguity in phylogenetic analyses based on morphology (Scotland et al., 2003).

In this paper, we stress the importance of defining characters in a phylogenetic context, such as in Wiley (1981: p. 116):

A character is a feature of an organism that is the product of an ontogenetic or cytogenetic sequence of previous features, or a feature of a previously existing parental organism(s). Such features arise in evolution by modification of a previously existing ontogenetic, cytogenetic, or molecular sequence.

This definition represents a transformational view of a character, reflecting the basis of homology. Although subjective, this definition stresses that characters must form transformational series of states in a phylogenetic scheme (Wiley 1981). Character states are observations or evolutionary steps of a trait, while characters represent a linked series of these character states (Fitzhugh, 2006). Wiley (1981) considers such differences in the definitions of characters and character states as merely semantic, but nevertheless recognizes that the codification of multistate characters represents the most important step in an hypothesis of phylogenetic relationships.

In other words, a character may appear in a modified state in a particular group of organisms, representing a synapomorphy for this taxon, as defined by Hennig (1966). The different forms presented by a character permit us to hypothesize a transformation series (Nelson and Platnick, 1981; Zeppelini, 2001, Amorim, 2002).

Discriminating a character with its modified states, that is, delimiting a transformation series, may be quite complex in phylogenetic reconstruction. This has led many authors to opt for a coding method known as binary coding. In this coding method, only two states appear: (0) absent (plesiomorphic), and (1) present (apomorphic). Sometimes a few multistate characters may be interspersed with the binary characters (Pleijel, 1995; Wilkinson, 1995). Binary coding is a "poorly defined" method, because only a single apomorphic state supports a taxon. Pleijel (1995) suggested that only such an "absent/present" coding method is sufficient to resolve phylogenetic relationships. However, this method fails to establish relationships among homologous states, such as recommended by Hennig (1966). Binary coding becomes purely phenetic, because it simply compares characters, without establishing relationships among them. It thus delimits groups by quantifying similarities, instead of referring to the expected outcome of evolutionary theory (Wiley, 1981; Wägele, 2004, 2005; Williams and Ebach, 2008; Kück and Wägele, 2016; Borkent, 2018).

Recently, Mooi and Gill (2010) severely criticized the hypotheses of molecular phylogeny, inferring that they do not establish relationships between plesiomorphic and apomorphic character states, and thus are provoking a crisis in fish systematics in particular. Molecular data are subject to statistical methods, instead of seeking relationships of homology. A long time ago, it was demonstrated that molecular data can be dealt with in the same way as morphological data (Christoffersen et al., 2004). Many 
molecular authors agree with Wägele $(2004,2005)$ that their approach is derived from global similarity. The implication is that present molecular methods are not Hennigian in outlook. Brower (2012) went further to explain that the phenetic component of molecular methods refers not only to "grouping by overall similarity", but also to the conversion of data from the original matrix into a secondary matrix of pairwise differences, from which overall similarities are assessed. This has caused an increase in the rate of homoplasy of structures, instead of providing phylogenetic inferences (Källersjö et al., 1999). We may add that, of course, assessing pairwise differences also represents a phenetic approach for establishing relationships.

Many concepts of homology have been proposed (Haszprunar, 1992; Hall, 1994; Laubichler, 2000; William, 2004; Szucsich and Wirkner, 2007; Nixon and Carpenter, 2011; Brower and de Pinna, 2012; Pavlinov, 2012). We accept a definition that summarizes homologous traits in an evolutionary context. We strive for methods that seek congruent patterns of common character origins and their evolutionary development.

Nixon and Carpenter (2011) revised the concept of homology and proposed a global concept of homology. In that work, they clarify that homology is not a synonym of synapomorphy, and that synapomorphy includes plesiomorphy. This corresponds closely to Hennig's original formulations of plesiomorphy, as representing relative concepts of homology. These authors also deduce that cladogram rooting inhances good hypotheses of homology (Nixon and Carpenter, 2011, p. 3, Figure 1), Homoplasies represent mistakes in phylogenetic analyses. Nixon and Carpenter (2011) also prefer to use phylogenetic homology, instead of homology based on ontogenetic similarity. Finally, they derive the terms "hypotheses of homology" and "homology", instead of the terms "primary homology" and "secondary homology", as presented by De Pinna (1991).

Brower and De Pinna (2012) disagreed with these authors on several accounts. The main objections were against the equivocal relations of homology and synapomorphy, and regarded the rooting of the tree in defining polarization. For Brower and De Pinna (2012), homology is equivalent to synapomorphy, and rooting is important for establishing character directionality in homology hypotheses. Finally, these authors redefine homology, with which we agree (p. 9):

Homology is the relationship among parts of organisms that provides evidence for common ancestry.

We support the view on the application of the phylogenetic method from morphological characters proposed by Mooi and Gill (2010). We also agree with them when they point out that methods based on similarity have provoked serious problems in the systematization of fishes. We must add that such problems are not restricted to fishes, but also apply to other groups, such as Annelida and Polychaeta.

Brower and De Pinna (2012) have a point when they consider homology equivalent to synapomorphy, and when they stress that characters must be well defined and coded when presenting an hypothesis of homology. Characters and their states produce a reliable topology when hypotheses of homology are reasonable, and should not be changed by character quantification, such as when using multiple sequences of DNA. Molecular data should be added to morphological information only if the former are treated in the same way as morphological data. That is, when interpreted as plesiomorphies and apomorphies.

The most relevant aspect in an investigation of genealogical relationship is the understanding of relationships among homologous traits and their integration into a general evolutionary scheme. A parsimony analysis should translate into a hierarchical pattern that reflects the evolutionary history of the group (Farris, 1969, 1970).

Braz. J. Biol. Sci., 2020, Vol. 7, No. 16, p. 119-147. 
The only scientific approach available in biology for incorporating the tremendous variety of organic forms into an ordered system is Phylogenetic Systematics. This approach includes theory and methods that are compatible with Biological Evolution. Evolution is the process responsible for the production of biodiversity. For this reason, only Phylogenetic Systematics is adequate as the basis for the production of a general reference system for Biological Systematics. The present crisis of ample proportion characterizing incongruences among available hypotheses regarding taxon composition and relationships can only reflect methodological inconsistencies in the dominant phylogenetic paradigm. Conflicting classifications demand restructuring of theoretical and methodological priorities in phylogenetic research. Such restructuring must arise from a change in the dominant paradigm, still couched in pre-Hennigian Neodarwinism. In times of increasing information output, more attention is necessary for considerations of the adequacy of methods and their congruence with the underlying available evolutionary theory.

\section{Annelida and Polychaeta as samples}

Annelida, traditionally divided into Polychaeta and Clitellata, is one of the largest groups of marine invertebrates, with circa of 16,500 described species (Blake, 1997). Annelids occur in several environments, from marine areas, limnetic zones, and terrestrial habitats (Struck, 2011; Struck et al., 2011).

Annelids present a great diversity of morphological characters, and this may be the reason why phylogenetic relationships of the Annelida or in the vicinity of the Annelida represents one of the most unresolved portions within the evolutionary history of the Metazoa (Rouse and Pleijel, 2001, 2007; Purschke et al., 2014; Parry et al., 2016; Chen et al., 2020).

In evolutionary history, proposals for the systematization of Annelida and Polychaeta have also caused confusion for present classification. At the same time, previous Hennigian proposals based on morphology, when not compatible with the latest overall similarity approaches, have been rejected (Rouse and Fauchald, 1995, 1997; EibyeJacobsen and Nielsen, 1997; Westheide, 1997; Westheide et al., 1999; Rouse and Pleijel, 2001; Purschke, 2002; Almeida et al., 2003; Bartolomaeus et al., 2005; Parry et al., 2016).

One of the first phylogenetic proposals presented for the Annelida is derived from the hydrostatic theory of Clark (1964). In this theory, the basic function of the coelom is to serve as a hydrostatic skeleton, through metameric subdivision of the coelom by septum that enable the organisms burrow into sediments faster or in a more powerful way. Subsequently, Clark (1969) established the origin of the parapodium as an evolutionary novelty of polychaetes, and Clitellata was placed at the base of the tree. Furthermore, in this proposal, the Annelida (with ancestors lacking segmented appendages), arise from articulated ancestors, becoming the sister group of the Arthropoda, although the legs of arthropods are not considered homologous to the parapodia of polychaetes (Figure 1).

Fauchald (1974) builds further on the original proposal of Clark (1964). His scheme is similar to the phylogenetic tree of Clark. He speculates that the stem species of Annelida have no parapodia, and thus the parapodia must have appeared later (Figure 2). 


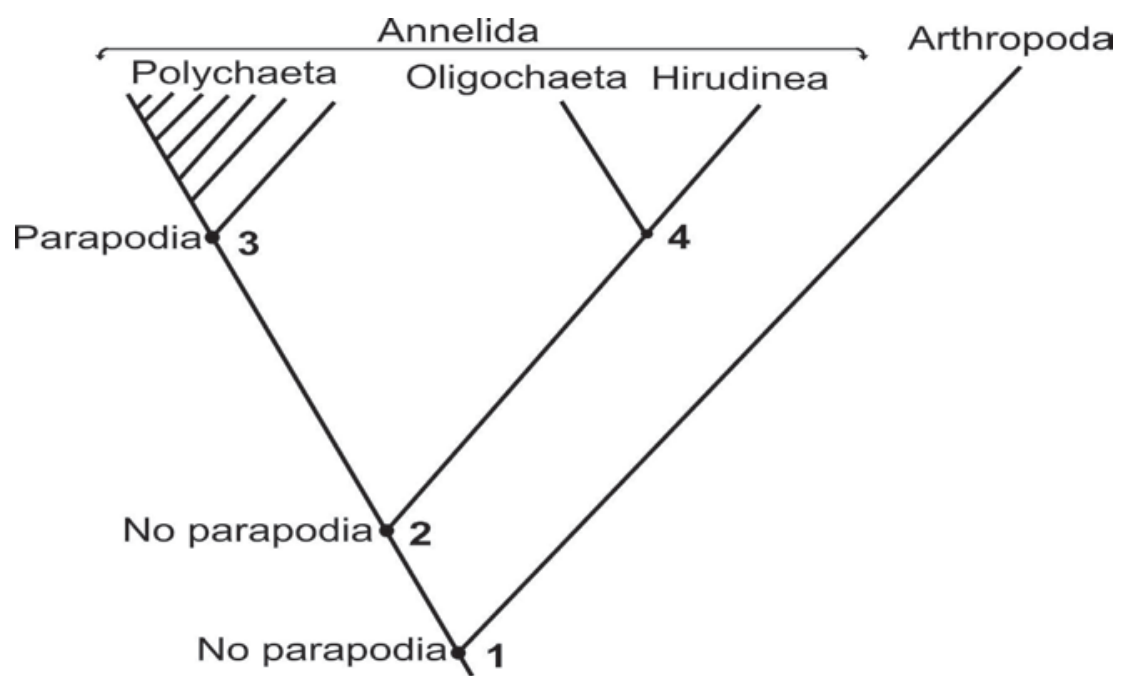

Figure 1. Phylogenetic scheme for Annelida, illustrating the origin of parapodia in polychaetes. Clitellates are in the base of the annelids, exemplifying the Hydrostatic Theory of Clark (1969). In this theory, the basic function of the coelom is to serve as a hydrostatic skeleton. Note that Arthropoda is the sister-group of Annelida. (Modified from Westheide, 1997).

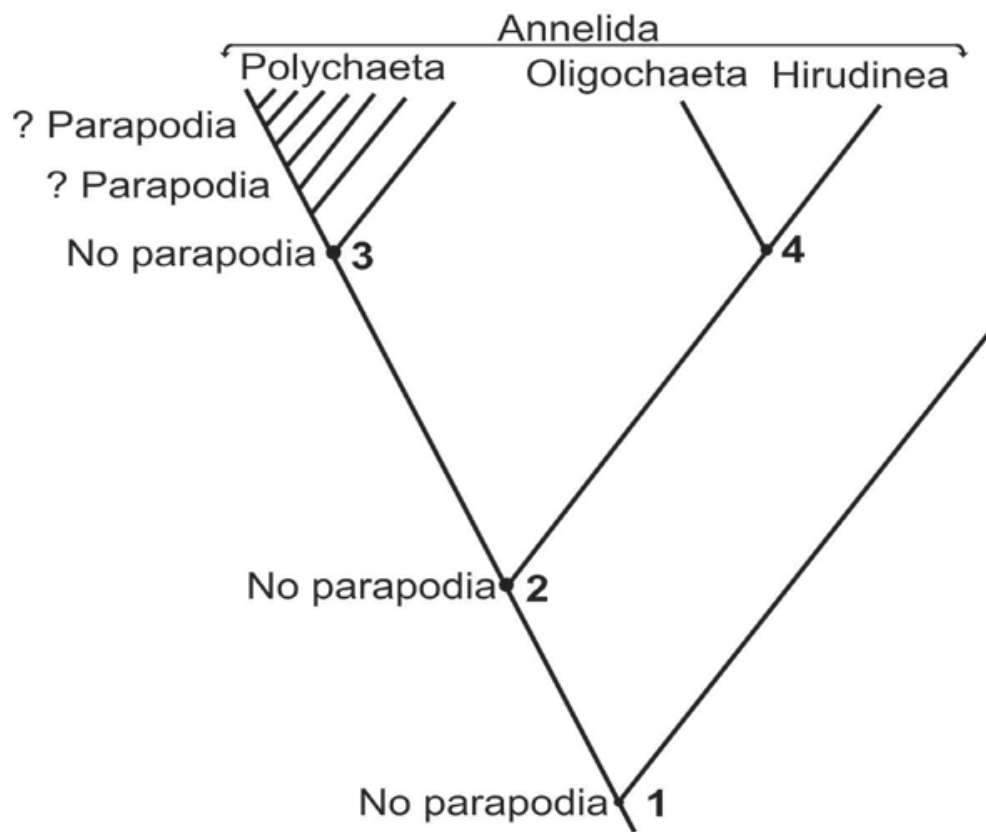

Arthropoda

Figure 2. Phylogenetic scheme of Annelida derived from polychaetes without parapodia. Clitellates are the sister-group of polychaetes, but the ancestral annelid does not have parapodia. Note that Arthropoda are the sister-group of Annelida. Scheme presented by Fauchald (1977). (Modified from Westheide, 1997).

Christoffersen and Araújo-de-Almeida (1994) were the first to propose a phylogeny of the Enterocoela as a group derived from annelids, concomitantly questioning the monophyly of both Annelida and Polychaeta. They established the broader monophylum Metameria to include all polychaetes and the remaining descendants of their 
common metameric ancestor. In this proposal, Pogonophora are the sister group of the Radialia and Deuterostomia (Figure 3).

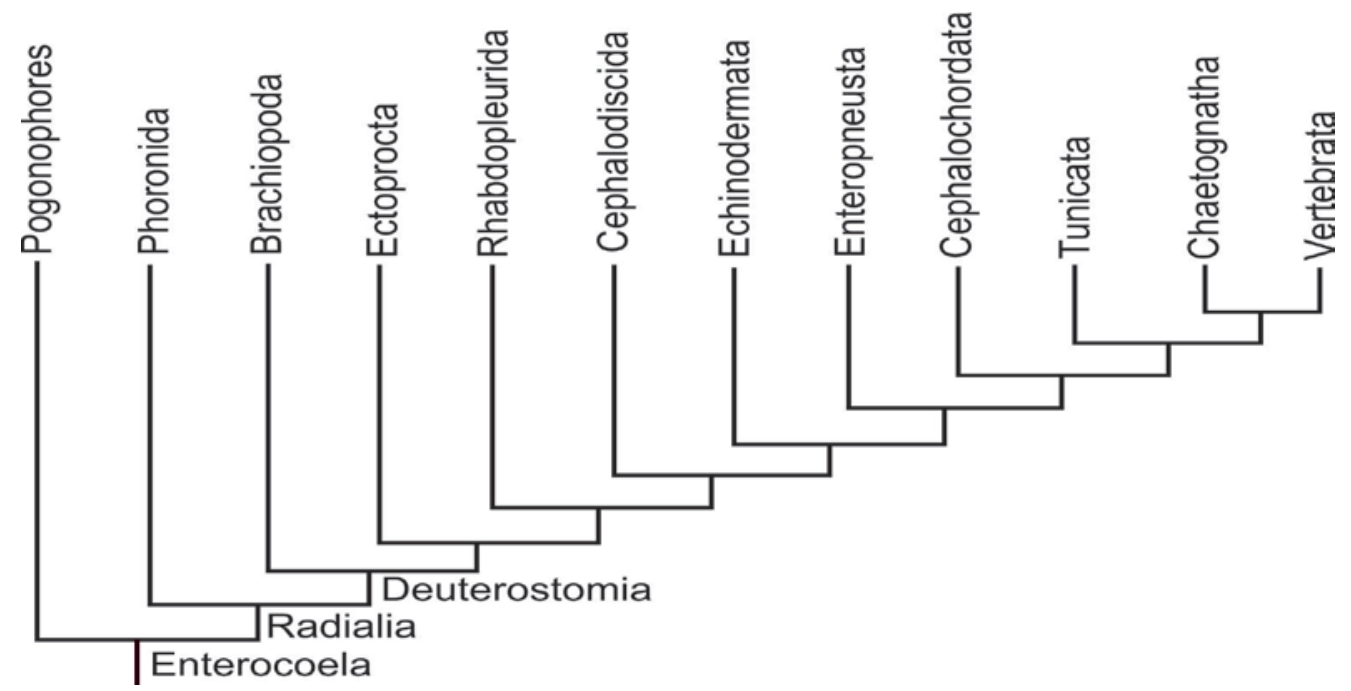

Figure 3. Phylogenetic scheme proposed for the basal groups of Enterocoela, enhancing relationships with sedentary polychaetes, pogonophorans, Radialia and Deuterostomia. In this proposal Polychaeta and Annelida are paraphyletic. Scheme presented by Christoffersen and Araújo-de-Almeida (1994). (Modified from Christoffersen and Araújo-de-Almeida, 1994).

Rouse and Fauchald (1995) presented a phylogenetic scheme based on morphology that included the Platyhelminthes, Onychophora, Euarthropoda, Echiura, Mollusca, Sipuncula, Nemertea, Clitellata, Pogonophora, Vestimentifera, and Polychaeta. In this scheme, Clitellata, Pogonophora, Vestimentifera and Polychaeta appeared closely related, despite the low resolution among these groups (Figure 4).

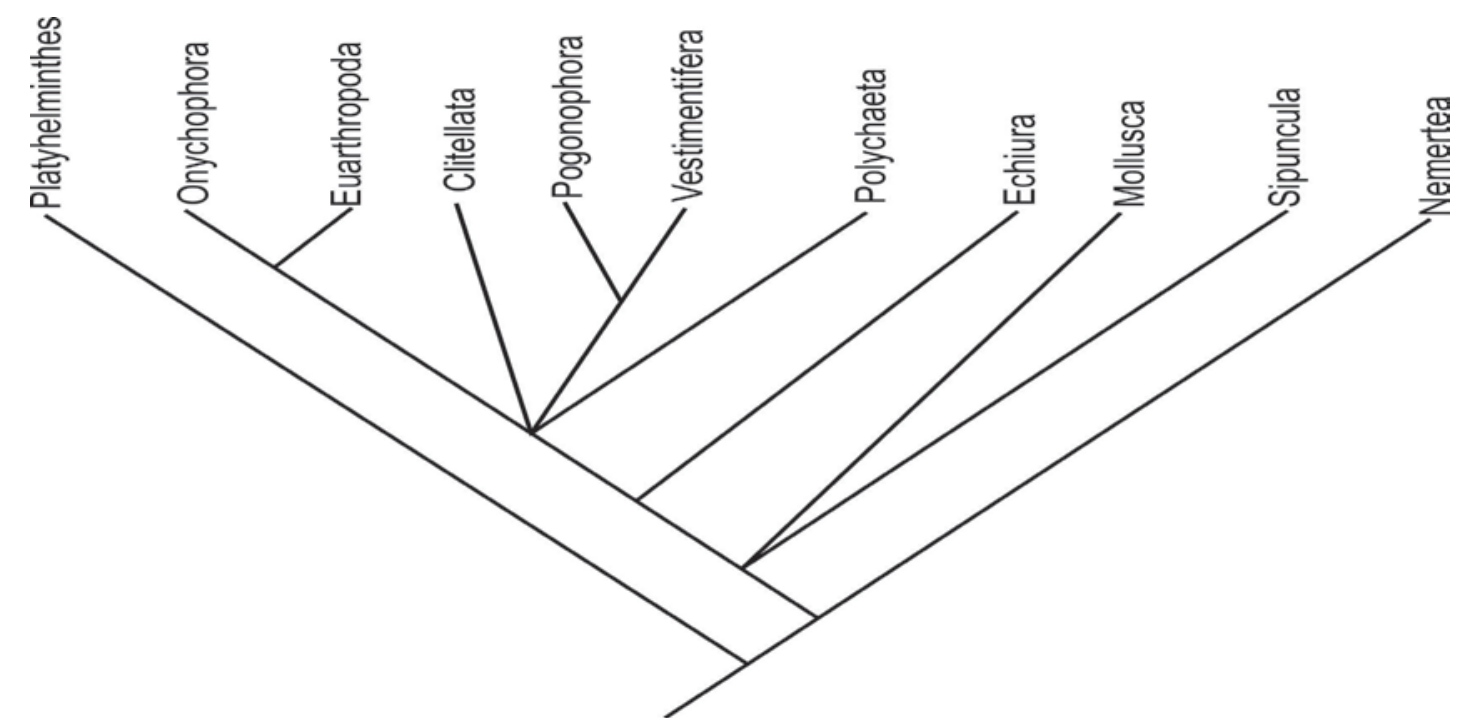

Figure 4. Phylogenetic scheme for the Articulata, with uncertain positions for Clitellata, Pogonophora, Vestimentifera, and Polychaeta (Modified from Rouse and Fauchald 1995). 
Westheide (1997), based on of the parapodial structures and internal anatomy, proposed a classification in which Oligochaeta derived from errant polychaetes. The loss of cephalic and parapodial structures was interpreted as being a derived state in the Clitellata, a view that is contrary to previous proposals (Clark, 1969; Fauchald, 1974, 1977) (Figure 5).

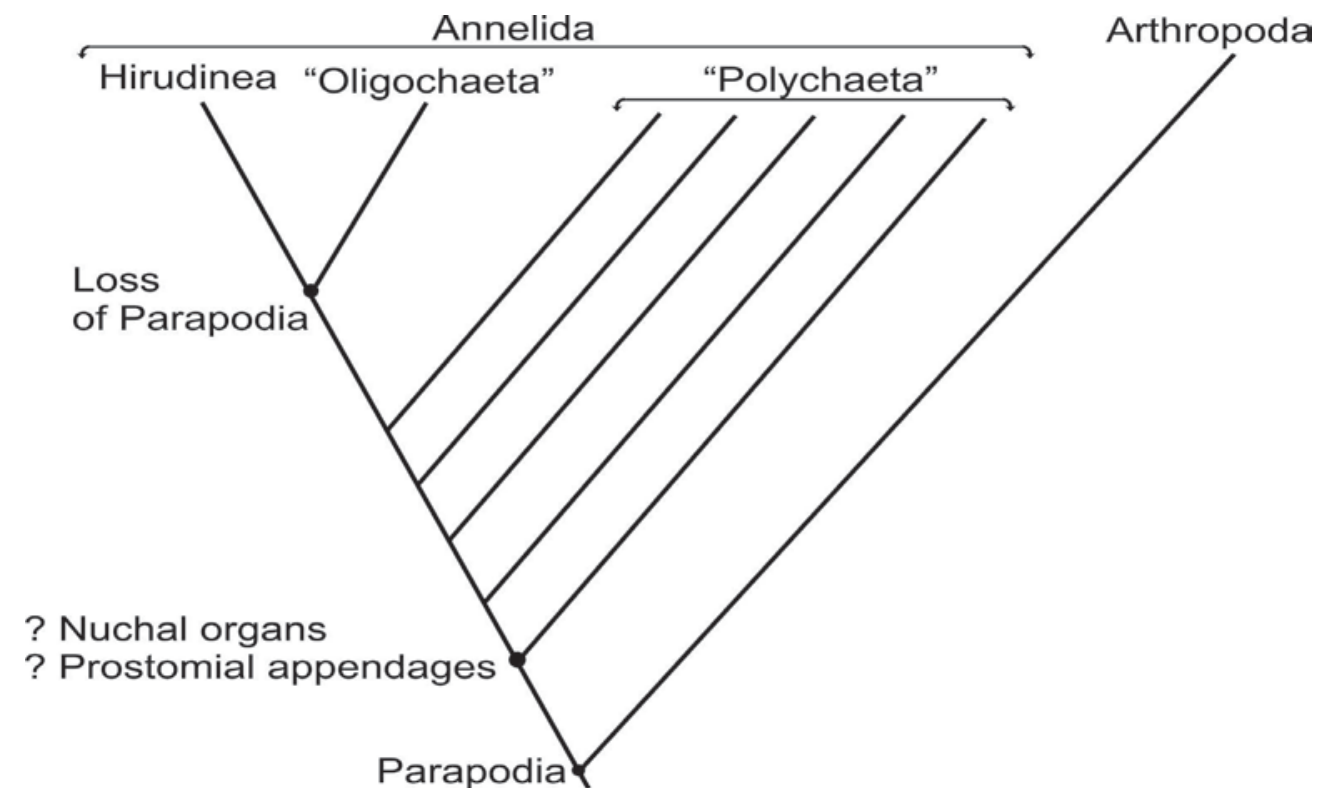

Figure 5. Phylogenetic scheme proposed for the Annelida. Note that this is the first proposal indicating the loss of parapodia in Clitellata, which have derived from "Polychaeta". In this scheme, the monophyly of the Polychaeta is indicated. Proposal of Westheide (1997) (Modified from Westheide. 1997).

McHugh (1997) presented the first phylogenetic proposal based on DNA sequences and on the nuclear gene elongation factor- $1 \alpha$. In this analysis, the groups included were species of polychaetes, clitellates, echiurans, molluscs, nemerteans, nematodes, arthropods, pogonophores, and chordates. Pogophophorans, clitellates and echiurans appear among the sedentary polychaetes (Figure 6).

Rouse and Fauchald (1997) proposed a cladistic classification of morphological characters, being the first to establish a phylogenetic scheme for the Annelida, including the Pogonophora as a family of Polychaeta - the Siboglinidae. This new taxon appeared as the sister group of Sabellariidae, Sabellidae, and Serpulidae (Figure 7).

Almeida et al. (2003) proposed a taxon Metameria, which included the paraphyletic groups Annelida and Polychaeta. For these authors, Metameria includes four main lineages. 1 - Echiura, with a phylogenetic position that is still uncertain within Annelida (Metameria) (Nielsen, 2012; Eibye-Jacobsen and Nielsen, 1997; McHugh 1997). Recent morphological and molecular data support the old view that Sternaspidae may be the sister group of the Echiura (McHugh, 2000; Almeida and Christoffersen, 2001). Other authors include the Echiura among the Capitellida. 2 - Arthropoda or Ecdysozoa as a derived group of the Annelida, in which arthropodia originated from polychaete parapodia (Walton, 1927; Manton, 1978, Almeida et al., 2003), and the elytra of Aphroditiformia, are homologous to the dorsal plates of marine lobopodes (Dzik and Krumbiegel, 1989). These homologies are further detailed in Almeida and Christoffersen (2001) and Almeida et al. (2001, 2008). 3 - Clitellata, that is related to the Questidae (Almeida and Christoffersen, 2001, Almeida et al., 2003; Garraffoni and Amorim, 2003; Christoffersen, 2007). 4 - 
Pogonophora, that is closely related to the sedentary and tubicolous Owenia fusiformis, and the oligomeric animals (Radialia), these groups share similarities between the trocophora and tornaria larvae (Gardiner, 1978, 1979; Christoffersen and Araújo-deAlmeida, 1994; Salvini-Plawen, 2000; Almeida and Christoffersen, 2001; Almeida et al., 2003; Ivanova-Kazas, 2007) (Figure 8). These proposals were also considered by paleontologists, who derive the vertebrates from segmented worms (Conway Morris, 2003a, b).

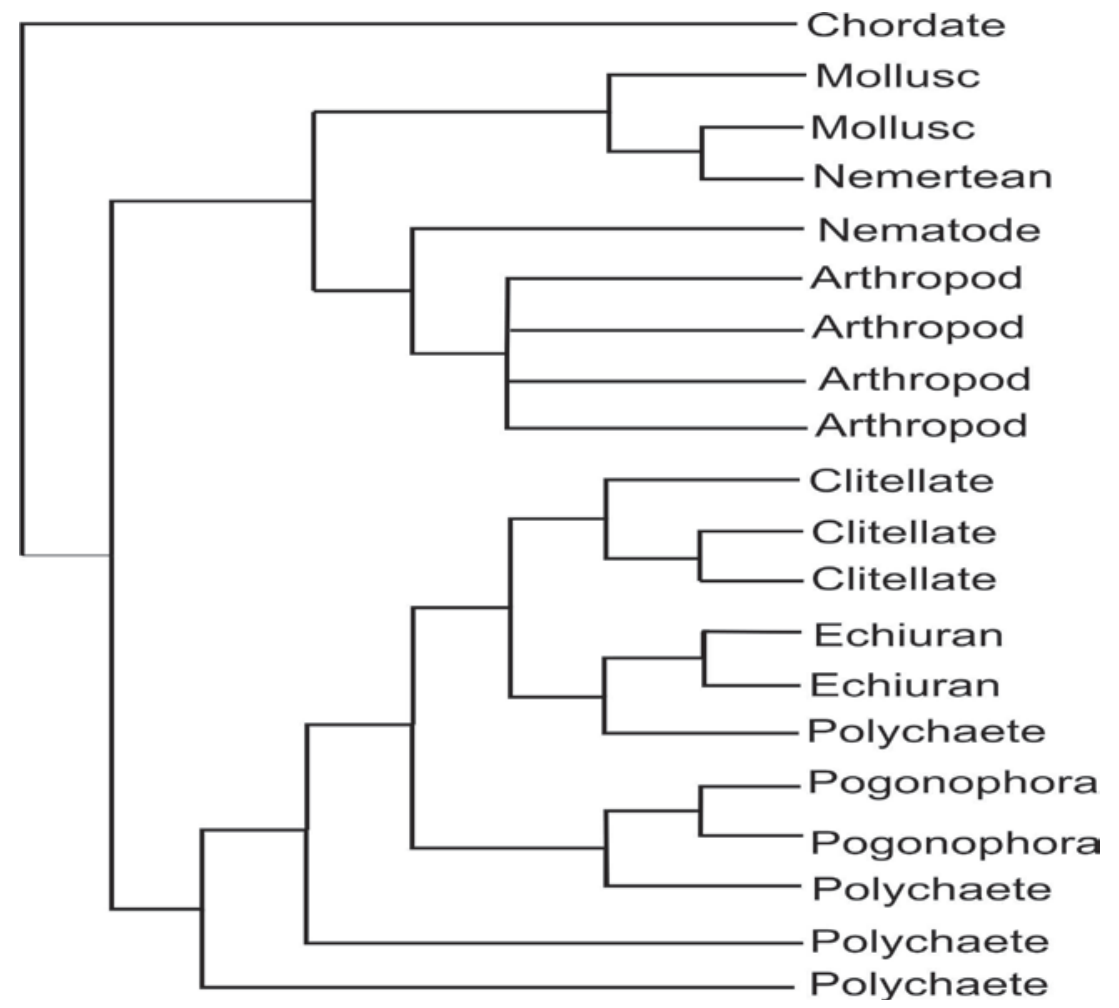

Figure 6. Phylogenetic framework proposed by McHugh (1997) based on molecular data deriving from DNA sequences and from the nuclear gene elongation factor-1 $\alpha$. (Modified from McHugh 1997).

Many papers on the phylogeny of Annelida and Polychaeta were y presented subsequently, that question the monophyly of both taxa Annelida and Polychaeta. These results favored the paraphyly of annelids and polychaetes, and thus remained incongruent with several morphological and molecular proposals (Eibye-Jacobsen and Nielsen, 1996; Westheide, 1997; McHugh, 1997, 2000; Almeida et al., 2003; Purschke 2000; Nielsen 2012).

The following genes were used in published molecular analyses: EF1 $\alpha$ (McHugh, 1997; 2000, Kojima, 1998), 18S rRNA (Bleidorn et al., 2003a, b), Histone H3, mLSU tRNA, and other gene fragments (Jennings and Halanych, 2005; Bleidorn et al., 2006), 18S rRNA, in combination with other gene fragments, such 28S rRNA, 16S rRNA, histone H3 or COI (Colgan et al., 2006; Rousset et al., 2007). Rousset et al. (2007) proposed a phylogeny for the Annelida based on combined molecular data, presenting two phylogenetic trees: one for the ensemble of complete data, the other for an ensemble of restricted data. However, the groups remain paraphyletic when compared to the proposal of Rouse and Fauchald (1997). Only a single order of Polychaeta is corroborated in this molecular work using multiple loci: the Amphinomida. 


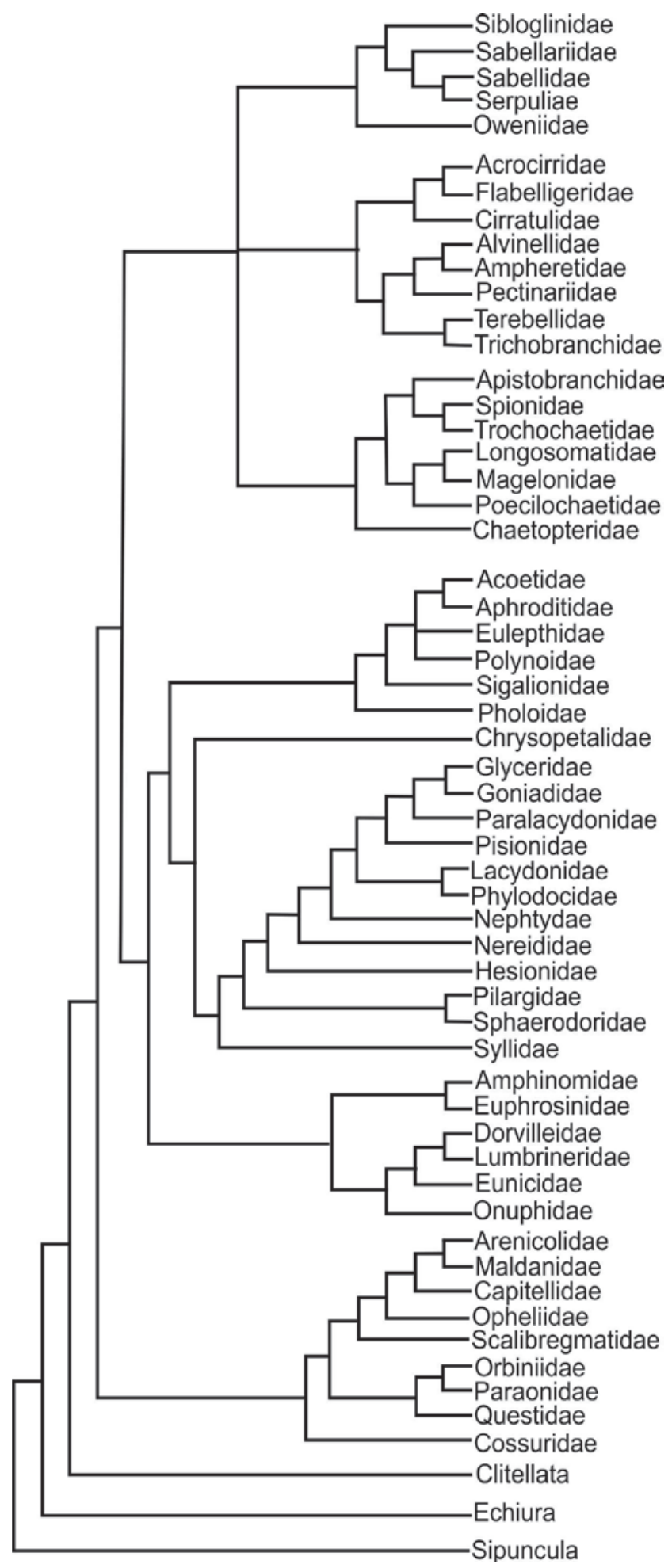

Figure 7. Scheme proposed by Rouse and Fauchald (1997) based on morphological data. In this proposal, Clitellata appear as the most basal group, from which the polychaetes derived. In this case, the cephalic appendages appear as evolutionary novelties.

Phylogenomic papers presented the Annelida in a phylogeny of the Metazoa, positioning them between "Lophotrochozoa" and "Protostomia" as a natural group (Struck 
et al., 2011; Kvist and Sidall, 2013; Weigert et al., 2014). Phylogenomics is the study of genetic mutations, while phylogenetics is the study of systematics relationships (Assis and Santos 2014). The objective of reconstructing the history and classification of present and past biodiversity, across multiple organizational levels, from semaphoront phenotypes and behaviours in a particular environment, solely from the geographical distributions of genes, is an untenable goal of phylogenomics.

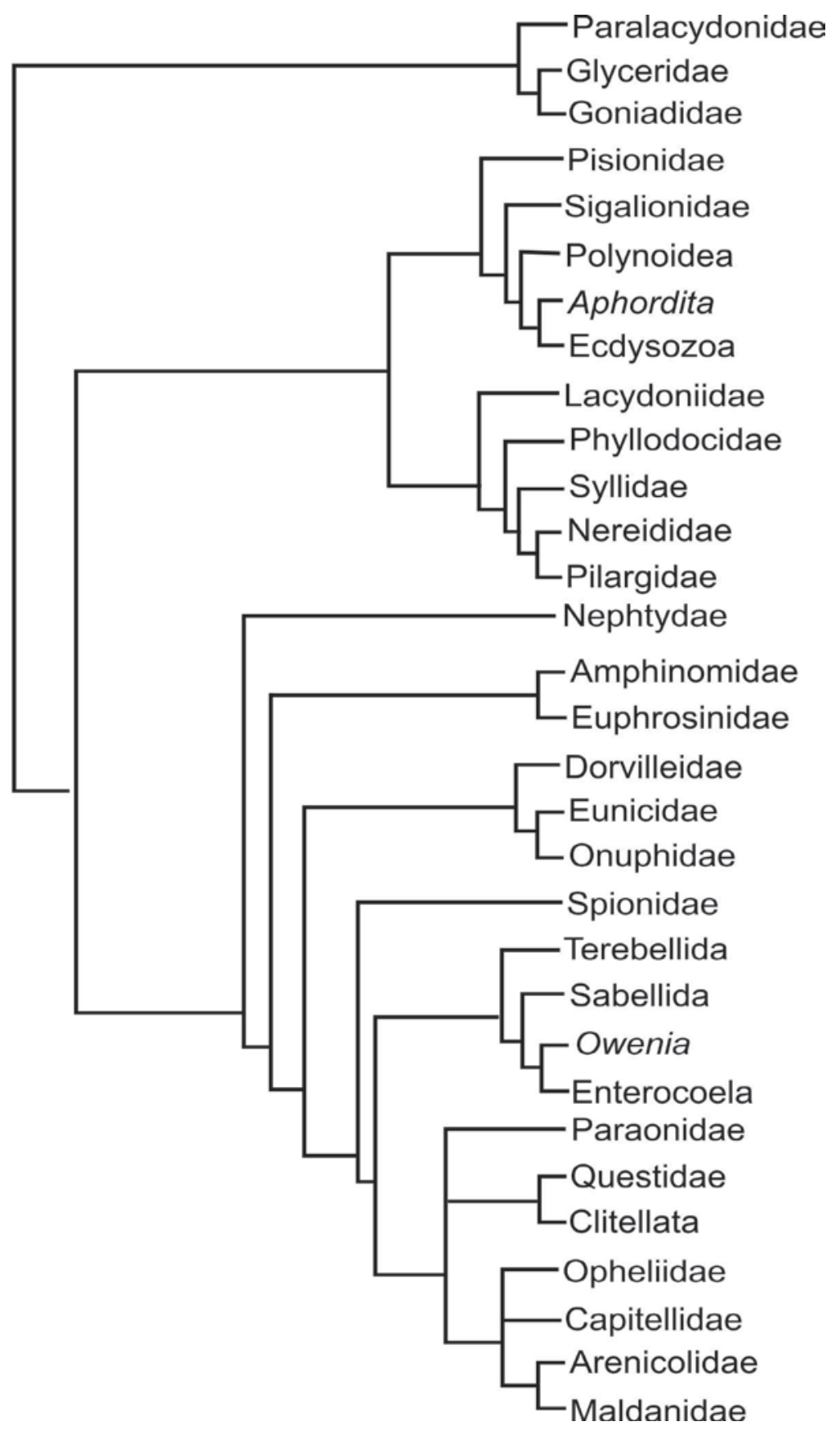

Figure 8. Scheme proposed by Almeida et al. (2003) based on morphological data. In this proposal, Clitellata appear as the sister group of the Questidae, and Owenia as the sister group of Enterocoela. Errantia polychaetes are placed basally. 
Struck et al. (2011) reinstate the old and artificial taxa Errantia and Sedentaria, based on a phylogenomic analysis of the Annelida. Both groups are inconsistent with morphological data, and are discrepant when compared to previous proposals based on morphology (Christoffersen and Araújo-de-Almeida, 1994; Eibye-Jacobsen, 1994; Rouse and Fauchald, 1997; Westheide, 1997; Almeida et al., 2003). Weigert et al. (2014) further corroborated the results of Struck et al. (2011) (Figure 9).

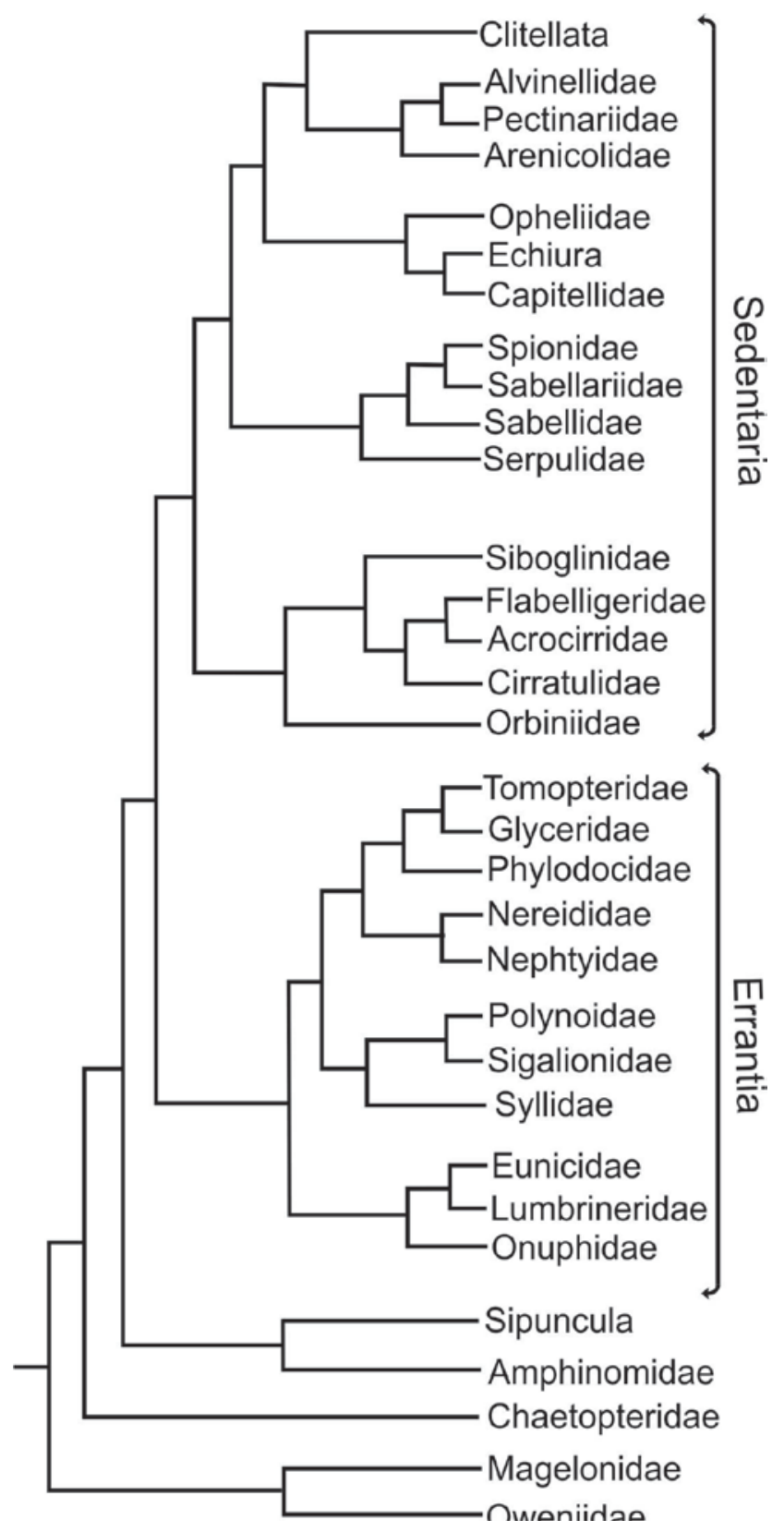

Figure 9. Scheme proposed by Weigert et al. (2014) based on molecular data. In this proposal, Errantia and Sedentaria were considered valid. Four families of polychaetes remained outside these two groups: Amphinomidae, Oweniidae, Chaetopteridae, Magelonidae, and Sipuncula (formally not an annelid). 
Contrary to these insights, recent consensus views continue to place Annelida as a valid taxon among the Lophotrochozoa, even when their position remains uncertain in this large incongruous group. Such uncertainties remain due to the incongruence of large data sets combined quantitatively in morphological and molecular approaches (Halanych, 2004).

Bartolomaeus $(1995,1996)$, Meyer and Bartolomaeus (1997), and Bartolomaeus et al. (2005) produced an important series of papers on the ontogeny of the chaetae. These authors compared the uncini of several polychaete groups with the chaetae of the Pogonophora. They derived a phylogeny in which the clades Oweniida, Terebellida, Pogonophora and Sabellida are strictly related. They only fail to agree that polychaete annelids are also closely related to the deuterostomes.

Although many papers attempted to justify the monophyly of the Annelida and Polychaeta, with hypotheses based on both morphology and molecules, the results remain incongruent when the tools for the establishment of primary homologies are used (De Pinna, 1991). The phylogenetic relationships proposed by Rouse and Fauchald (1995, 1997) were unsatisfactory and did not gain consensus among researchers, although some authors find these results convincing (Rousset et al., 2007; Rouse and Pleijel, 2007). These problems become crucial for the understanding of the evolutionary history of the Metazoa, because Annelida (Polychaeta), Pogonophora and Deuterostomia remain the least resolved groups in the evolutionary history of animals.

Starting in the 1980s, a confrontation occurred among researchers around of the world regarding the position of the Pogonophora in at least four pathways:

1) As an independent phylum among the protostomes (Jones, 1985a, b; Southward, 1975, 1999; Southward et al., 2002);

2) As an independent phylum among the deuterostomes, related to the hemichordates (Johansson, 1937; Hyman, 1959; Ivanov, 1955a, 1955b, 1955c, 1960, 1988; Siewing 1975; Malakhov et al., 1997; Ivanova-Kazas, 2007);

3) As a family of polychaetes within the Annelida, the Siboglinidae (Rouse and Fauchald, 1995, 1997; Rouse, 2001; Schulze, 2003; Bartolomaeus et al., 2005; Pleijel et al., 2009);

4) As a group placed between the paraphyletic protostomes and the monophyletic deuterostomes (Christoffersen and Araújo-de-Almeida, 1994; Almeida and Christoffersen, 2001; Winchell et al., 2002; Almeida et al., 2003; De Assis and Christoffersen, 2010).

The reduction of the Phylum Pogonophora to a family of Polychaeta (Rouse and Fauchald, 1997) thus breaks an old evolutionary paradigm, which considers this taxon as belonging to the Deuterostomia (Gardiner, 1978, 1979; Christoffersen and Araújo-deAlmeida, 1994; Salvini-Plawen, 2000; Almeida and Christoffersen, 2001; Almeida et al., 2003). Some recent research accepts Pogonophora as a phylum closely related to hemichordates (Ivanov, 1960, 1988; Gardiner, 1978, 1979; Ivanova-Kazas, 2007), others now believe that these animals represent a family of polychaetes (Rouse and Fauchald, 1997; Rouse, 2001), and a third group establishes these animals as a transitional group between annelids and deuterostomes (Christoffersen and Araújo-de-Almeida, 1994; Almeida and Christoffersen, 2001; Almeida et al., 2001; De Assis and Christoffersen, 2010).

The phylogenetic relationships established by Rouse and Fauchald $(1995,1997)$, although still much used (Rousset et al., 2007; Rouse and Pleijel, 2007), do not represent a consensus view among researchers. The hypothesis of Rouse and Fauchald (1997) neglects the view that Annelida (Clitellata, Polychaeta, and Pogonophora) and related invertebrates represent the most unresolved node in the evolutionary history of the 
Metazoa (Struck et al., 2011). The change in the status of the Phylum Pogonophora to the polychaete family Siboglinidae (Polychaeta) (Rouse and Fauchald, 1995, 1997) thus discontinues an evolutionary tradition in which this group shares a relationship with Enterocoela (Gardiner, 1978, 1979; Christoffersen and Araújo-de-Almeida, 1994; SalviniPlawen, 2000; Almeida and Christoffersen, 2001; Almeida et al., 2003).

These antagonistic phylogenetic systematizations thus result from different phylogenetic proposals (contrast Rouse and Fauchald, 1997 with Almeida and Christoffersen, 2001). Note that Rouse and Fauchald (1997) advocate the monophyly of Annelida and Polychaeta, while Almeida and Christoffersen (2001) reinforce the paraphyly of both groups. The paraphyly of Annelida and Polychaeta was first proposed by Christoffersen and Araújo-de-Almeida (1994).

The most recent proposal for the Annelida includes the taxa Oweniidae, Magelonidae, Chaetopteridae, Amphinomidae and Sipuncula at the base of the Errantia and Sedentaria (Weigert et al., 2014). Oweniidae was placed basally on the basis of deuterostome characters, such as a largely intraepidermal nervous system (Bubko and Minichev, 1972), a mitraria larva with monociliated epidermal cells, nephridia with deuterostome similarities (Smith et al., 1987; Smart and Von Dassow, 2009), and monociliated epidermal cells in the adults (Gardiner, 1978; Westheide, 1997; SalviniPlawen, 2000; De Assis and Christoffersen, 2010). The larvae of Magelona mirabilis (Magelonidae) likewise possess an epidermis made up of monociliated cells, according to Bartolomaeus (1995). The position of Chaetopteridae and Amphinomidae are not considered in that paper. The taxon Chaetopteridae is considered to have the body divided into four parts herein, but the phylogenetic position is considered unstable (Moore et al., 2017). Other authors have no doubt that this is a sedentary group of polychaetes. Amphinomidae is an errant group of polychaetes, placed within Eunicida and related to Euphrosioidae (Rouse and Fauchald, 1997). Interestingly, the new proposal based on molecular data excludes these very significant taxa from the scenario just presented. This makes no sense for a proposal that regards annelids and polychaetes as being monophyletic taxa (Weigert et al., 2014).

Parry et al. (2016) point out significant differences between analysis of transcriptomes as compared to results based on morphology and fossils. The phylogenetic relationships proposed by Parry et al. (2016) through parsimony analysis from morphological characters (recent and fossilized organisms), (Figure 10) had showed the taxa Chaetopterus (Chaetopteridae) and Owenia (Oweniidae) among the "sedentary" polychaetes, while Myzostoma (Myzostomidae), Eurythoe and Euphrosine (Amphinomidae) appeared within the monophyletic clade Aciculata, contrary to the proposal of Weigert et al. (2014). The above authors further demonstrated that Polychaeta, Scolecida, Sedentaria and Pleistoannelida were not supported in all analyses, which suggests that the annelid ancestral was a macroscopic and epibenthic animal, with aligned palps and prominent parapodial lobes with many capillary chaetae, and the secondary reduction of this complex body plan is widespread in numerous related taxa, what had caused confusion in annelid phylogeny using only morphological data from extant taxa.

Braz. J. Biol. Sci., 2020, Vol. 7, No. 16, p. 119-147. 


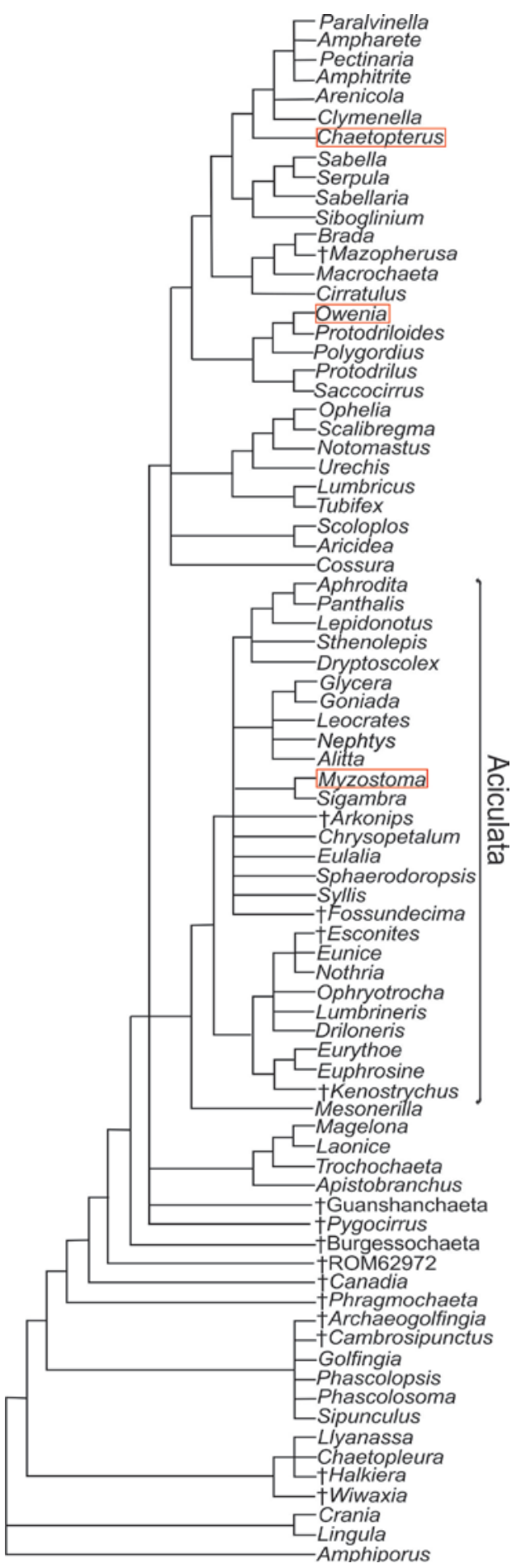

Figure 10. Phylogenetic proposal based on Parry et al. (2016), based on morphological of extant and extinct organisms. The parsimony analysis showed that Aciculata is a monophyletic taxon in all analysis. This proposal suggests that the annelid ancestral was a macroscopic and epibenthic animal, with aligned palps and prominent parapodial lobes with many capillary chaetae (modified from Parry et al., 2016) Note that Chaetopterus and Owenia appeared between sedentary polychaetes, while Myzostoma within monoplyletic Aciculata. 
Above we have present the available proposals for the systematization of the Polychaeta and Annelida produced along to the evolutionary history of the annelids. We also present our point of view, that is based on the main modified structures: a) palp evolution-the most basal palps are short and sensorial, and can be found in eunicid species, the majority of dorvilleids have long palps, but the they have a sensorial function, the spionids, chaetopterids, and magelonids present a pair of long palps, which are feeding and sensorial, multiple feeding and sensorial palps can be shown in Terebelliformia and Cirratuliformia, but they are disorganized structures (Figure 11). Besides, other characters, such as tagmatization and segment reduction, result in a compartmentalized body, modified larval trocophores are similar to the tornaria larvae, with multiple ciliated bands observed in oweniids, pogonophorans present an intraepithelial nervous system that is characteristic of Epineuralia (Oligomera + Chordata) (Salvini-Plawen, 2000).

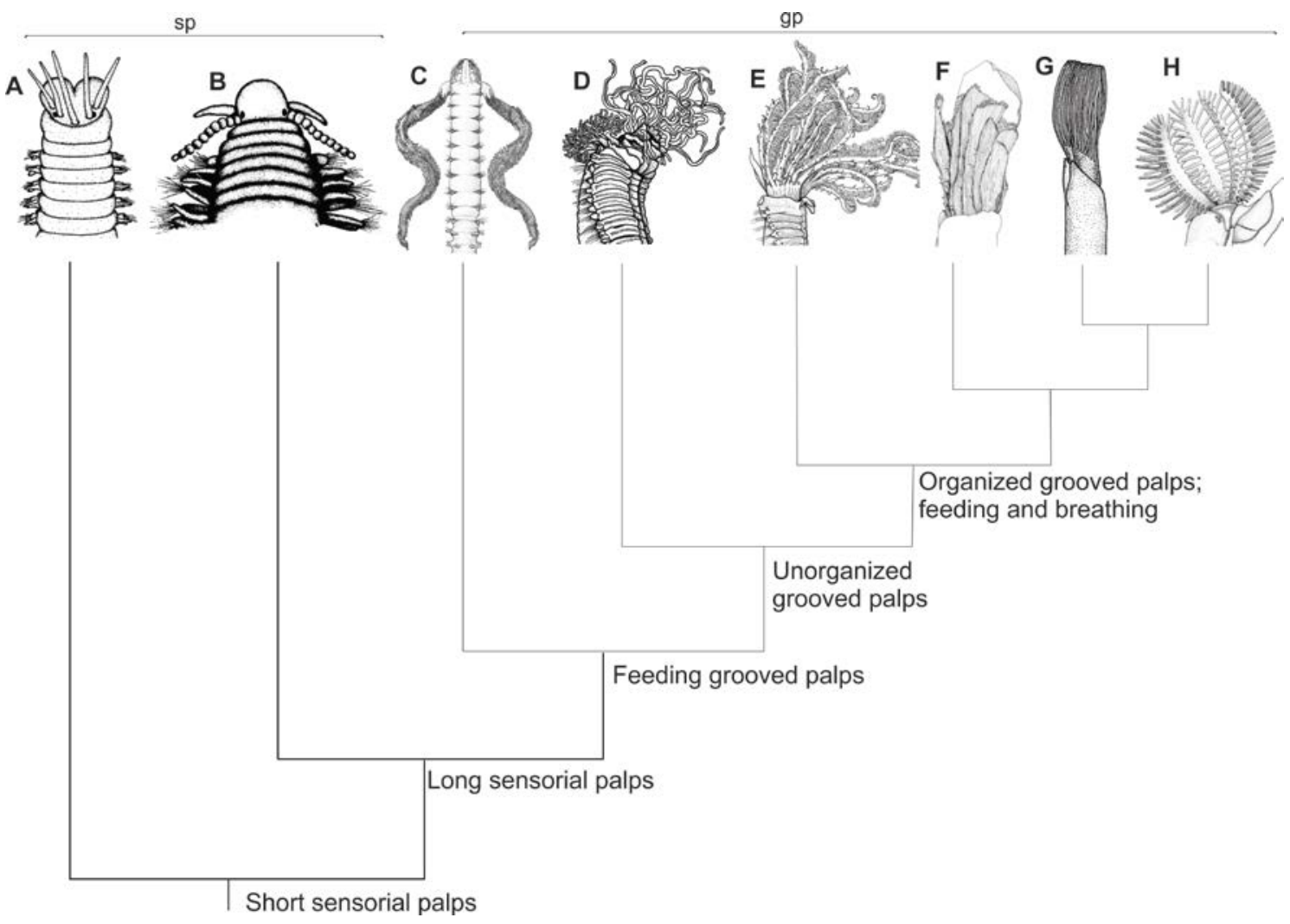

Figure 11. Phylogenetic proposal based on Almeida et al. (2003). The proposal indicated the evolution of the palps, which serve both for feeding and for breathing (A, Modified from Steiner and Amaral, 2000, B, Modified from Blake, 1997, C, D, E Modified from Glasby et al., 2000, F, Modified from Southward et al., 2011, G, Modified Temereva, 2000, H, Modified from Lester, 1985); gp: grooved palps; sp: sensorial palps. Illustrative figures without scales.

Bright et al. (2013) sketched different pathways of larval development from the metatrochophore to the adult in frenulates and vestimentiferans. They showed a coelomic cephalic cavity in both taxa. In the trochophore larvae of polychaetes the head arises from micromeres of the first two quartets belonging to all four quadrants. These are then joined by the stomodeum, that arises from the micromeres of the 3rd quarter. The entire anterior region of the body, including the coelomic mesoderm and the secondary mouth, is derived 
from cells belonging to quadrant B in pogonophores. Usually there is no coelom in the head of polychaetes, in contrast to pogonophores. The close relationship between pogonophores and polychaetes is derived exclusively on data from molecules (IvanovaKazas, 2016).

The hypotheses that consider deuterostomes as derived from protostomes have become more consistent with the study of ontogeny (Arendt and Nübler-Jung 1994, 1996, 1997, 1999; Nübler-Jung and Arendt, 1999; Winchell et al., 2002). Homeotic genes demonstrate that these genes are responsible for the dorsoventral and anteroposterior body axes, as well the segmentation found in polychaetes, arthropods, and vertebrates (Mcginnis et al., 1984; Lawrence, 1990; François and Bier, 1995; Holley et al., 1995; Jones and Smith, 1995; Holland et al., 1997; Tautz, 2004; Brown et al., 2008). Studies comparing the cerebral cortex and the production of neurotransmitters in humans, fishes, and polychaetes, have discovered homologues for the formation of these neurotransmitters between polychaete worms and vertebrates deriving from a common ancestor (TessmarRaible et al., 2007; Tomer et al., 2010; Sweeney and Luo, 2010). Arendt et al. (2004) found rhabdomeric photoreceptor cells and ciliated photoreceptor cells in the brain of the annelid Platynereis sp. These rhabdomeric photoreceptor cells are also found in insects (arthropods), while ciliated photoreceptor cells are found in vertebrates. Later, Osorio (2011) found ciliated photoreceptor cells in the larva of Terebratalia (Brachiopoda). This demonstrates a homology relationship among the photoreceptor cells, and indicates that polychaetes have both types of cells. While arthropods have one type of cell (rhabdomeric photoreceptors), vertebrates have the other type (cilated photoreceptors), thus establishing a relationship of ancestry and descent of arthropods from polychaetes on the one side, and of vertebrates from polychaetes on the other.

In these scenarios, we hope that the world scientists will be able to choose relationships that represent the best evolutionary scenario for the unresolved relationship of annelids and the others metazoan animals, or that some of them can show a convincing proposal of monophyly for this taxon. This is one more proof that molecular approaches are not producing understandable topologies for the larger and older animal groups, and are not resolving the systematics of problematic groups. Despite the importance of molecular data, we question the validity of these proposals, and the use of this tool for the proposition of phylogenetic scenarios. De Carvalho and Ebach (2009) similarly lamented the emphasis on quantitative analyses and the abstraction of characters and organisms alike as statistical values and models.

In this case, the molecular approach has caused confusion and unwarranted restructuring of annelid systematics, such as has occurred in the phylogeny of fishes, diptera and others groups (Mooi and Gill, 2010; Borkent, 2018).

Although many decades have passed and several hypotheses of relationships have been proposed, both with morphological and with molecular data, we recognize that annelid phylogeny has no present consensus, especially in the cases in which morphology (living and fossilized organisms) and molecular approaches remain dissociated (Bright et al., 2013; Ivanova-Kazas, 2016; Parry et al., 2016). The presence of similar chaetae in Brachiopoda, polychaetes, and clitellates (Storch and Welsch, 1972; Gustus and Cloney, 1972; Orrhage, 1973; Lüter and Bartolomaeus, 1997), and nuchal grooves in Sipuncula (Adrianov et al., 2006), put into question the monophyletic status established for Annelida and Polychaeta. We are convinced of the paraphyly of annelids and polychaetes, based on the lack of exclusive and shared morphological characters in these groups. Homoplasy remains the last resource when we seek to interpret causal observations. Thus, we regarded Annelida, Pleistoannelida, Lophotrochozoa, and Protostomes as paraphyletic taxa.

Finally, we return to Salvini-Plawen's (2000) original question: What is convergent/homoplastic in Pogonophora? 


\section{Conclusion}

We conclude that genetic data are very important for the recognition of distinct populations, being a useful tool for the recognition of species, as performed in several molecular studies. In particular, we illuminate the case of species-complexes, where morphology is unable to distinguish valid subgroups (Wheeler, 2005; Álvarez-Campos et al., 2016; Budaeva et al., 2016; Saglam et al., 2016; Kara et al., 2020). For the hypotheses of phylogenetic relationships among larger groups, such as phyla, classes and orders, molecular data should however be avoided, even in the case of multiple genes. This is because present statistical methods access character similarities and differences, which are not adequate for the detection of hierarchical patterns in nature. Phylogeny without plesiomorphic character states clearly distinguished from true synapomorphies is not phylogeny, but only a single phenetic dendrogram based on general similarly.

\section{Acknowledgments}

We acknowledge FACEPE (2014-2015) for a post-doctoral scholarship to J. E. De Assis, and CNPq (Conselho Nacional de Desenvolvimento Científico e Tecnológico) for a productivity grant to M.L. Christoffersen.

\section{Conflicts of interest}

The authors declare that they have no conflicts of interest.

\section{References}

Adrianov, A. V.; Malakhov, V. V.; Maiorova, A. S. Development of the tentacular apparatus in sipunculans (Sipuncula): I. Thysanocardia nigra (Ikeda, 1904) and Themiste pyroides (Chamberlin, 1920). Journal of Morphology, v. 267, p. 569-583, 2006. https://doi.org/ 10.1002/jmor.10423

Almeida, W. O.; Christoffersen, M. L.; Amorim, D. S.; Elloy, E. C. C. Morphological support for the position of Pentastomida and related fossils. Biotemas, v.21, p.81-80, 2008. https://doi.org/10.5007/2175-7925.2008v21n3p81

Almeida, W. O.; Christoffersen, M. L.; Amorim, D. S.; Garraffoni, A. R. S; Sene, S. G. Polychaeta, Annelida, and Articulata are not monophyletic: Articulating the Metameria (Metazoa, Coelomata). Revista Brasileira de Zoologia, v. 20, p. 23-57, 2003. https://doi.org/10.1590/S0101-81752003000100006

Almeida, W. O; Christoffersen, M. L. Análise cladística dos grupos basais de Metameria: uma nova proposta para o posionamento dos Arthropoda e grupos afins entre os poliquetas errantes. Ribeirão Preto: Holos Editora, 2001.

Álvarez-Campos, P.; Sergio, T.; San Martín, G.; Leiva, C.; Riesgo, A. Phylogenetic relationships and evolution of reproductive modes within flattened syllids (Annelida: Syllidae) with the description of a new genus and six new species. Invertebrate Systematics, v. 32, p. 224-251, 2018. https://doi.org/10.1071/IS17011

Amorim, D. S. Elementos da Sistemática Filogenética. Ribeirão Preto: Holos Editora, 2002.

Arendt, D.; Nübler-Jung, K. Common ground plans in early brain development in mice and flies. BioEssays, v. 18, p. 255-259, 1996. https://doi.org/10.1002/bies.950180314 
Arendt, D.; Nübler-Jung, K. Comparison of early nerve cord development in insects and vertebrates. Development, v. 126, p. 2309-2325, 1999.

Arendt, D.; Nübler-Jung, K. Dorsal or ventral: Similarities in fate maps and gastrulation patterns in annelids, arthropods and chordates. Mechanisms of Development, v. 61, p. 7-21, 1997. https://doi.org/10.1016/S0925-4773(96)00620-X

Arendt, D.; Nübler-Jung, K. Inversion of dorsoventral axis? Nature, v. 371, p. 26, 1994. https://doi.org/10.1038/371026a0

Arendt, D.; Tessmar-Raible, K.; Snyman, H.; Dorresteijn, A. W.; Wittbrodt, J. Ciliary photoreceptors with a vertebrate-type opsin in an invertebrate brain. Science, v. 306, p. 869-871, 2004. https://doi.org/10.1126/science.1099955

Assis, L. C. S. Are homology and synapomorphy the same or different? Cladistics, v. 29, p. 7-9, 2012. https://doi.org/10.1111/j.1096-0031.2012.00431.x

Assis, L. C. S.; Santos, L. M. Phylogenetics is not phylogenomics. Cladistics, v. 30, p. 8-9, 2014. https://doi.org/10.1111/cla.12028

Bartolomaeus, T. Structure and formation of the uncini in Pectinaria koreni, Pectinaria auricoma (Terebellida) and Spirorbis spirorbis (Sabellida): Implications for annelid phylogeny and the position of the Pogonophora. Zoomorphology, v. 115, p. 161-177, 1995. https://doi.org/10.1007/BF00403171

Bartolomaeus, T. Ultrastructure and formation of hooked setae in Owenia fusiformis Delle Chiaje, 1842: Implications for annelid phylogeny. Canadian Journal of Zoology, v. 74, p. 2143-2153, 1996. https://doi.org/10.1139/z96-243

Bartolomaeus, T.; Purschke, G.; Hausen, H. Polychaete phylogeny based on morphological date: A comparison of current attempts. Hydrobiologia, v. 535/536, p. 341-356, 2005. https://doi.org/10.1007/s10750-004-1847-5

Beaty, J. The evolutionary contigency thesis. Proceedings of the II Pittsburg-Konstanz Colloquium in the Philosophy of Science, 1993, Pittsbugh, University of Pittsburghy Press, 1995.

Blake, A. J. The Annelida. Part 1. Introduction to Polychaeta. In: Black, A. J.; Hilbig, B.; Scott, P. H. (Eds.). Taxonomic atlas of the benthic fauna of the Santa Barbara Channel. Santa Barbara, California, 1997. p. 39-133.

Bleidorn, C.; Podsiadlowski, L.; Bartolomaeus, T. The complete mitochondrial genome of the orbiniid polychaete Orbinia latreillii (Annelida, Orbiniidae): A novel gene order for Annelida and implications for annelid phylogeny. Gene, v. 370, p. 96-103, 2006. https://doi.org/10.1016/j.gene.2005.11.018

Bleidorn, C.; Vogt, L.; Bartolomaeus, T. New insights into polychaete phylogeny (Annelida) inferred from 18S rDNA sequences. Molecular Phylogenetics and Evolution, v. 29, p. 279-288, 2003. https://doi.org/10.1016/S1055-7903(03)00107-6

Borkent, A. The state of phylogenetic analysis: Narrow visions and simple answers: Examples from the Diptera (flies). Zootaxa, v. 4374, p. 107-143, 2018. https://doi.org/ 10.11646/zootaxa.4374.1.7

Bright, M.; Eichinger, I.; von Salvini Plawen, L. The metamorphose of a deep-sea hydrothermal vent vestimentiferan (Polychaeta: Sibodlinidae). Organisms, Diversity \& Evolution, v. 13, p. 163-188, 2013. https://doi.org/10.1007/s13127-012-0117-z

Brooks, D. R.; McLennan, D. A. The nature of diversity: An evolutionary voyage of discovery. Chicago: The University of Chicago Press, 2002. 
Brooks, D. R.; Wiley, E. O. Theories and methods in different approaches to phylogenetic systematics. Cladistics, v. 1, p.1-11, 1985. https://doi.org/10.1111/j.1096-0031.1985. tb00407.x

Brower, A. V. Z.; de Pinna, M. C. C. Homology and errors. Cladistics, v. 1, p. 1-10, 2012. https://doi.org/10.1111/j.1096-0031.2012.00398.x

Brower, A.V.Z. The meaning of "phonetic". Cladistics, v. 28, p. 113-114, 2012. https://doi.org/10.1111/j.1096-0031.2011.00374.x

Brown, F. D.; Prendergast, A.; Swalla, B.J. Man is but a Worm: Chordate origins. Genesis, v. 46, p. 605-613, 2008. https://doi.org/10.1002/dvg.20471

Bubko, O. V.; Minichev, Y. S. The nevous system in Oweniidae. Zoologichesckii Zhurnal, v. 51 , p. $1288-1299,1972$.

Budaeva, N.; Schepetov, C.; Zanol, J.; Neretina, T.; Willassen, E. When molecules support morphology: Phylogenetic reconstruction of the Family Onuphidae (Eunicida, Annelida) based on 16S rDNA and 18S rDNA. Molecular Phylogenetics and Evolution, v. 94, p. 791-801, 2015. https://doi.org/10.1016/j.ympev.2015.10.011

Carnap, R. The methodological character of theoretical concepts. In: Feigl, H.; Scriven, M. (Eds.). The foundations of Science and the concepts of Psychology and Psychoanalysis. Minneapolis: University of Minnesota Press, 1956.

Carpenter, J. M. Choosing among multiple equality parsimonious cladograms. Cladistics, v. 2, p. 291-296, 1998. https://doi.org/10.1111/j.1096-0031.1988.tb00476.x

Chen, H.; Parry, L. A.; Vinther, J; Zhai, D.; Hou, X.; Ma, X. A Cambrian crown annelid reconciles phylogenomics and the fossil record. Nature, v. 583, p. 249-252, 2020. https://doi.org/10.1038/s41586-020-2384-8

Christoffersen, M. L. Clitellate evolution and leech diversity: Glossifoniidae excl. Helobdella (Annelida: Hirudinea: Hhynchobdellida) from South America. Gaia Scientia, v. 1, p. 131-140, 2007.

Christoffersen, M. L.; Araújo, M. E.; Moreira, M. A. M. A molecular method for a qualitative analysis of potentially coding sequences of DNA. Brazilian Journal of Biology, v. 64, p. 383-398, 2004. https://doi.org/10.1590/S1519-69842004000300003

Christoffersen. M. L.; Araújo-de-Almeida. E. A phylogenetic framework of the Enterocoela (Metameria: Coelomata). Revista Nordestina de Biologia, v. 9, p. 173-208, 1994.

Clark, C.; Curran, D. J. Outgroup analysis, homoplasy, and global parsimony: A response to Maddison, Donoghue, and Maddison. Systematic Zoology, v. 35, p. 422-426, 1986. https://doi.org/10.1093/sysbio/35.3.422

Clark, R. B. Dynamics in metazoan evolution. The origin of the coelom and segments. Oxford: Clarendon Press; 1964.

Clark, R. B. Systematics and Phylogeny: Annelida, Echiura, Sipuncula. Chemical Zoology 4. New York: Academic Press, 1969.

Colgan, D. J.; Hutchings, P. A.; Braune, M. A multigene framework for polychaete phylogenetic studies. Organisms, Diversity \& Evolution, v. 6, p. 220-235, 2006. https://doi.org/10.1016/j.ode.2005.11.002

Conway-Morris, S. Once we were worms. New Scientist, v. 179, p. 34-37, 2003. 
De Assis, J. E.; Christoffersen, M. L. Pogonophora (Siboglinidae) are not polychaetes: A systemic view of metamerian animals. Revista Nordestina de Biologia, v. 19, p. 55-76, 2010.

De Carvalho, M. R.; Ebach, M. C. Death of the specialist, rise of the machinist. History and Philosophy of the Life Sciences, v. 31, p. 467-470, 2009.

De Pinna, M. C. C. Concepts and test of homology in the cladistic paradigm. Cladistics, v. 7, p. 367-394, 1991. https://doi.org/10.1111/j.1096-0031.1991.tb00045.x

De Queiroz, K. The ontogenetic method determining character polarity and its relevance to phylogenetic systematics. Systematics Zoology, v. 34, p. 280-299, 1985. https://doi.org/ 10.1093/sysbio/34.3.280

Donoghue, M. J.; Cantino, P. D. The logic and limitations of the outgroup substitution approach to cladistic analysis. Systematics Botany, v. 9, p. 19-202, 1984.

Dretske, F. I. Laws of nature. Philosophy of Science, v. 44, p. 248-268, 1977. https://doi.org/10.1086/288741

Dzik, J.; Krumbiegel, G. The oldest 'onychophoran' Xenusium: A link connecting phyla? Lethaia, v. 22, p. 169-181-1989. https://doi.org/10.1111/j.1502-3931.1989.tb01679.x

Eibye-Jacobsen, D.; Nielsen, C. Point of view: the rearticulation of annelids. Zoologica Scripta, v. 25, p. 275-282, 1996. https://doi.org/10.1111/j.1463-6409.1996.tb00166.x

Fang, F. C.; Casadevall, A. Reductionistic and holistic science. Infection and Immunity, v. 79, p. 1401-1404, 2011. https://doi.org/10.1128/IAI.01343-10

Farris, J. A successive approximations approach to character weighting. Systematics Zoology, v. 18, p. 374-385, 1969. https://doi.org/10.2307/2412182

Farris, J. Methods for computing Wagner trees. Systematics Zoology, v. 19, p. 83-92, 1970. https://doi.org/10.2307/2412028

Fauchald, K. Polychaeta phylogeny: A problem in protostome evolution. Systematics Zoology, v. 23, p. 493-506, 1974. https://doi.org/10.1093/sysbio/23.4.493

Fauchald, K. The polychaete worms: Definitions and keys to the orders, families and genera. Natural History Museum of Los Angeles County, Science Series, v. 28, p. 1-190, 1977.

Fitzhugh, K. Species as explanatory hypotheses: Refinements and implications. Acta Biotheoretica, v. 57, p. 201-248, 2009. https://doi.org/10.1007/s10441-009-9071-3

Fitzhugh, K. The philosophical basis of character coding for the inference of phylogenetic hypotheses. Zoologica Scripta, v. 35, p. 261-286, 2006. https://doi.org/10.1111/j.14636409.2006.00229.x

François, V.; Bier, E. Xenopus chordin and Drosophila short gastrulation genes encode homologous proteins functioning in dorsal-ventral axis formation. Cell, v. 80, p. 19-20, 1995. https://doi.org/10.1016/0092-8674(95)90446-8

Gardiner, S. L. Fine structure of Owenia fusiformis (Polychaeta: Oweniidae) and its significance for annelid phylogeny. Chapel Hill: University of North Carolina, 1979. (Ph.D. Thesis).

Gardiner, S. L. Fine structure of the ciliate epidermis on the tentacles of Owenia fusiformis (Polychaeta, Oweniidae). Zoomorphologie, v. 91, p. 37-48, 1978. https://doi.org/ 10.1007/BF00994152 
Garraffoni, A. R. S.; Amorim, D. S. Análise filogenética de Questidae e Clitellata: o problema da parafilia de "Polychaeta". Iheringia, Série Zoologia, v. 93, p. 97-109, 2003. https://doi.org/10.1590/S0073-47212003000100011

Glasby, C. J.; Hutchings, P. A.; Fauchald, F.; Paxton, H.; Rouse, G. W.; Watson, R. C.; Wilson, R. S. Class Polychaeta. In: Beesley, P. L.; Ross, G. J. B.; Glasby, C. J. (Eds.). Polychaetes \& allies: The Southern Synthesis. Fauna of Australia. Vol. 4A. Polychaeta, Myzostomida, Pogonophora, Echiura, Sipuncula. Melbourne: CSIRO Publishing, 2000, p. 1-296.

Goloboff, P. A. Methods for faster parsimony analysis. Cladistics, v. 12, p. 199-220, 1996. https://doi.org/10.1111/j.1096-0031.1996.tb00009.x

Goloboff, P. A.; Farris, J. S.; Nixon, K. C. TNT, a free program for phylogenetics analysis. Cladistics, v. 24, p. 774-786, 2008. https://doi.org/10.1111/j.1096-0031.2008.00217.x

Grandcolas, P.; Guilbert, E.; Robillard, T.; D’Haese, A.; Murienne, J; Legendre, F. Mapping characters on tree with or without the outgroups. Cladistics, v. 20, p. 579-582, 2005. https://doi.org/10.1111/j.1096-0031.2004.00037.x

Gustus, R. M.; Cloney, R. A. Ultrastructural similarities between chaetae of brachiopods and polychaetes. Acta Zoologica, v. 53, p. 229-233, 1972. https://doi.org/10.1111/j.14636395.1972.tb00590.x

Halanych, K. M. The new view of animal phylogeny. Annual Review of Ecology, Evolution, and Systematics, v. 35, p. 229-256, 2004. https://doi.org/10.1146/annurev. ecolsys.35.112202.130124

Hall, B. K. Homology: The hierarchical basis of comparative Biology. New York: Academic Press, 1994.

Haszprunar, G. The types of homology and their significance for evolutionary biology and phylogenetics. Journal of Evolutionary Biology, v. 5, no. 1, p. 13-24, 1992. https://doi.org/10.1046/j.1420-9101.1992.5010013.x

Hempel, C. G. Aspects of scientific explanation, and other essays in the philosophy of science. New York: Free Press, 1965.

Hempel, C. G. Oppenheim, P. Studies in the logic of explanation. Philosophy of Science, v. 15, p. $135-175,1948$.

Hennig, W. Phylogenetic Systematics. Urbana: University of Illinois Press, 1966.

Holland, L. Z.; Kene, M.; Williams, N. A.; Holland, N. Sequence and embryonic expression of the amphioxus engrailed gene (AmphiEn): The metameric pattern of transcription resembles that of its segment-polarity homolog in Drosophila. Development, v. 124, p. 1723-1732, 1997.

Holley, S. A.; Jackson, P. D.; Sasai, Y.; Lu, B.; Robertis, E. M. Hoffmann, F. M.; Ferguson, E. L. Conserved system for dorsal-ventral patterning in insects and vertebrates involving sog and chordin. Nature, v. 376, p. 249-253, 1995. https://doi.org/10.1038/376249a0

Hyman, L. H. The invertebrates: Smaller coelomate groups. New York: McGraw-Hill, 1959.

Ivanov, A. V. Analysis of the embryonic developmental of Pogonophora in connection with the problems of phylogenetics. Journal of Zoological Systematics and Evolutionary Research, v. 26, p. 161-185, 1998. https://doi.org/10.1111/j.1439-0469.1988.tb00308.x

Ivanov, A. V. The main features of the organization of Pogonophora. Systematics Zoology, v. 4, p. 171-174, 1955a. https://doi.org/10.2307/2411669

Braz. J. Biol. Sci., 2020, Vol. 7, No. 16, p. 119-147. 
Ivanov, A. V. On external digestion in Pogonophora. Systematics Zoology, v. 4, p. 174-176, 1955b. https://doi.org/10.2307/2411670

Ivanov, A. V. On the assignment of class Pogonophora to a separate phylum of Deuterostomia: Brachiata. A. Ivanov, Phyl. Nov. Systematics Zoology, v. 4, p. 177-178, 1955c. https://doi.org/10.2307/2411671

Ivanov, A.V. Embranchement des Pogonophores. In: Grassé, P. P. (Ed.). Traité de Zoologie. Paris: Masson, 1960. p. 1521-1622. v. 5, 2.

Ivanova-Kazas, O. M. Molecules, morphology, and phylogeny. Paleontology Journal, v. 50, p. 1474-1476, 2016.

Ivanova-Kazas, O. M. On the problem of the origin of Pogonophora. Russian Journal of Marine Biology, v. 33, p. 338-342, 2007. https://doi.org/10.1134/S1063074007050124

Jennings, R. M.; Halanych, K. M. Mitocondrial genomes of Clymenella torquata (Maldanidae) and Riftia pachyptila (Siboglinidae): Evidence for conserved gene order in Annelida. Molecular Phylogenetics and Evolution, v. 22, p. 210-222, 2005. https://doi.org/ 10.1093/molbev/msi008

Johansson, K. E. Über Lamellisabella zachsi und ihre systematische Stellung. Zoologischer Anzeiger, v. 117, p. 23-26, 1937.

Jones, C. M.; Smith, J. C. Revolving vertebrates. Current Biology, v. 5, p. 474-476, 1995.

Jones, M. L. On the Vestimentifera, new phylum: Six new species, and other taxa, from hydrothermal vents and elsewhere. Bulletin of the Biological Society of Washington, v. 6 , p. 117-158, 1985.

Jones, M. L. Vestimentiferan pogonophores: Their biology and affinities. In: Morris, S. C.; George, J. D. R.; Platt, H. M. G. (Eds.). The origin and relationships of lower invertebrates. Cambridge: Oxford University Press, 1985. (The Systematic Association, Special Vol. 28). p. 327-342.

Källersjö, M.; Albert, V. A.; Farris, J. S. Homoplasy increases phylogenetic structure. Cladistics, v. 15, p. 91-93, 1999. https://doi.org/10.1111/j.10960031.1999.tb00400.x

Kara, J.; Santos, C. S. G.; Macdonald, A. H. H.; Simon, C. A. Resolving the taxonomic identities and genetic structure of two cryptic Platynereis Kinberg species from South Africa. Invertebrate Systematics, v. 34, p. 618-636, 2020. https://doi.org/10.1071/IS19072

Kluge, A. G.; Farris, J. S. Quantitative phyletics and the evolution of anurans. Systematic Zoology, v. 18, p. 1-32, 1969. https://doi.org/10.2307/2412407

Kluge, A. G.; Strauss, R. E. Ontogeny and systematic. Annual Review of Ecology, Evolution, and Systematics, v. 16, p.247-268, 1985. https://doi.org/10.1146/ annurev.es.16.110185.001335

Kojima, S. Paraphyletic status of Polychaeta suggested by phylogenetic analysis based on the amino acid sequences of elongation factor X. Molecular Phylogenetics and Evolution, v. 9, p. 255-261, 1998. https://doi.org/10.1006/mpev.1997.0472

Kück, P.; Wägele, W. Plesiomorphic character states cause systematic errors in molecular phylogenetic analyses: A simulation study. Cladistics, v. 32, p. 461-478, 2016. https://doi.org/10.1111/cla.12132

Kuhn, T. S. The structure of scientific revolutions. 2. ed. Chicago: University Press, 1970. 
Kvist, S.; Siddall, M. E. Phylogenomics of Annelida revisited: A cladistic approach using genome-wide expressed sequence tag data mining and examining the effects of missing data. Cladistics, v. 29, p. 435-448, 2013. https://doi.org/10.1111/cla.12015

Laubichler, M. D. Homology in development and the development of the homology concept. American Zoologist, v. 40, p. 777-788, 2000. https://doi.org/10.1093/ icb/40.5.777

Lawrence, P. A. Compartments in vertebrates? Nature, v. 344, p. 382-383, 1990. https://doi.org/10.1038/344382a0

Lester, S. M. Cephalodiscus sp. (Hemichordata: Pterobranchia): Observations of functional morphology, behaviour and occurence in shallow water around Bermuda. Marine Biology, v. 85, p. 263-268, 1985. https://doi.org/10.1007/BF00393246

Lüter, C.; Bartolomaeus, T. The phylogenetic position of Brachiopoda: A comparison of morphological and molecular data. Zoologica Scripta, v. 26, p. 245-253, 1997. https://doi.org/10.1111/j.1463-6409.1997.tb00414.x

Malakhov, V. V.; Popelyaev, I. S.; Galkin, S. A. On the position of Vestimentifera and Pogonophora in the system of the Animal Kingdom. Zoologichesckii Zhurnal, v. 76, p. 1336-1347, 1997.

Manton, S. M. The Arthropods: Habits, functional morphology and evolution. Oxford: Clarendon Press, 1977.

Martínez, S. F. Reducionismo em Biologia: uma tomografia da relação Biologia-sociedade. In: Abrantes, P. C. (Ed.). Filosofia da Biologia. Porto Alegre: Artmed, 2011. p. 37-59.

McGinnis, W.; Hart, C. P.; Gehring, W. J.; Ruddle, F. H. Molecular cloning and chromosome mapping of a mouse DNA sequence homologous to homeotic genes of Drosophila. Cell, v. 38, p. 675-680, 1984. https://doi.org/10.1016/0092-8674(84)90262-9

McHugh, D. Molecular evidence that echiurans and pogonophorans are derived annelids. PNAS, v. 94, p. 8006-8009, 1997. https://doi.org/10.1073/pnas.94.15.8006

McHugh, D. Molecular phylogeny of the Annelida. Canadian Journal of Zoology, v. 78, p. 1873-1884, 2000.

Mickevich, M. F. Transformation series analysis. Systematic Zoology, v. 31, p. 461-478, 1982.

Mickevich, M. F.; Lipscomb, D. L. Parsimony and the choice between alternative transformations for the same data set. Cladistics, v. 7, p.111-139, 1991. https://doi.org/ 10.1111/j.1096-0031.1991.tb00028.x

Mooi, R. D.; Gill, A. C. Phylogenies without synapomorphies: A crisis in fish systematics. Zootaxa, v. 2450, p. 26-40, 2010.

Moore, J. M.; Nishi, E.; Rouse, G. W. Phylogenetic analyses of Chaetopteridae (Annelida). Zoologica Scripta, v. 46, p. 596-610, 2017. https://doi.org/10.1111/zsc.12238

Nelson, G.; Platnick, N. Systematics and Biogeography: Cladistics and vicariance. New York: Columbia University Press, 1981.

Nelson, G. Outgroup and ontogeny. Cladistics, v.1, p. 29-45, 1985. https://doi.org/ 10.1111/j.1096-0031.1985.tb00409.x

Nielsen, C. Animal evolution: Interrelationships of the living phyla. 3. ed. New York: Oxford University, 2012. 
Nixon, K. C.; Carpenter, J. M. On outgroup. Cladistics, v. 9, p. 413-462, 1993. https://doi.org/10.1111/j.1096-0031.1993.tb00234.x

Nixon, K. C; Carpenter, J. M. On homology. Cladistics, v. 28, p. 160-169, 2011. https://doi.org/10.1111/j.1096-0031.2011.00371.x

Nixon, K. C.; Carpenter, J. M. More on homology. Cladistics, v. 28, p. 225-226, 2012. https://doi.org/10.1111/j.1096-0031.2011.00388.x

Nübler-Jung, K. N.; Arendt, D. Dorsoventral axis inversion: Enteropneust anatomy links invertebrates to chordates turned upside down. Journal of Zoological Systematics and Evolutionary Research, v. 37, p.93-100, 1999. https://doi.org/10.1046/j.14390469.1999.372106.x

O'Grady, R. T.; Deets, G. B. Coding multistate characters, with special reference to the use of parasites as characters of their hosts. Systematic Zoology, v. 36, p. 268-279, 1987. https://doi.org/10.2307/2413066

Orrhage, L. Light and electron microscope studies of some brachiopod and pogonophoran chaetae. With a discussion of the 'annelid chaetae' as a phylogenetic-systematic character. Zeitschrift für Morphologie der Tiere, v.74, p. 253-270, 1973. https://doi.org/ 10.1007/BF00636879

Osorio, D. Evidence that a larval brachiopod has ciliary photoreceptors that are directionally selective, and therefore may function as eyes, bears on an enduring puzzle about photoreceptor evolution in animals. Nature, v. 472, p. 300-301, 2011. https://doi.org/10.1038/472300a

Parry, L. A.; Edgecombe, G. D.; Eibye-Jacobsen, D.; Vinther, J. The impact of fossil date on annelid phylogeny inferred from discret morphological characters. Proceedings of the Royal Society B, Biological Sciences, v. 283, p.1-9, 2016. https://doi.org/10.1098/ rspb.2016.1378

Pavlinov, I. Ya. The contemporary concepts of homology in Biology: A theoretical review. Biology Bulletin Reviews, v. 2, no. 1, p. 36-54, 2012. https://doi.org/10.1134/ S2079086412010057

Pigliucci, M. On the different ways of 'doing theory' in Biology. Biological Theory, v. 7, p. 287-297, 2012. https://doi.org/10.1007/s13752-012-0047-1

Pimentel, R. A.; Riggins, R. The nature of cladistics data. Cladistics, v. 3, no. 3, p. 201-209, 1987. https://doi.org/10.1111/j.1096-0031.1987.tb00508.x

Pleijel, F. On character coding for phylogenetic reconstruction. Cladistics, v. 11, p. 309315, 1995. https://doi.org/10.1111/j.1096-0031.1995.tb00092.x

Pleijel, F.; Dahlgren, T; Rouse, G. W. Progress in systematic: From Siboglinidae to Pogonophora and Vestimentifera and back to Siboglinidae. Comptes Rendus Biologies, v. 332, p. 140-148, 2009. https://doi.org/10.1016/j.crvi.2008.10.007

Purschke, G. On the ground pattern of Annelida. Organisms Diversity \& Evolution, v. 2, p. 181-196, 2002. https://doi.org/10.1078/1439-6092-00042

Purschke, G.; Bleidorn, C.; Struck, T. Systematics, evolution and phylogeny of Annelida: A morphological perspective. Memoirs of Museum Victoria, v. 71, p. 247-269, 2014.

Rouse, G. W. A cladistic analysis of Siboglinidae Caullery, 1914 (Polychaeta, Annelida): Formerly the Phyla Pogonophora and Vestimentifera. Zoological Journal of the Linnean Society, v. 132, p. 55-80, 2001. https://doi.org/10.1006/zjls.2000.0263 
Rouse, G. W.; Fauchald, K. The articulation of annelids. Zoologica Scripta, v. 24, p. 269-301, 1995. https://doi.org/10.1111/j.1463-6409.1995.tb00476.x

Rouse, G. W.; Pleijel, F. Annelida. Zootaxa, v. 1668, p. 245-264, 2007.

Rouse, G. W.; Pleijel, F. Polychaetes. Oxford: Oxford University Press, 2001.

Rouse, G. W.; Fauchald, K. Cladistics and Polychaetes. Zoologica Scripta, v. 26, p. 139-204, 1997. https://doi.org/10.1111/j.1463-6409.1997.tb00412.x

Rousset, V.; Pleijel, F.; Rouse, G. W.; Erséus, C.; Siddall, M. E. A molecular phylogeny of annelids. Cladistics, v. 23, p.41-63, 2007. https://doi.org/10.1111/j.10960031.2006.00128.x

Saglam, S.; Saunders, R.; Lang, S. A.; Shain, D. H. A new species of Hirudo (Annelida: Hirudinidae): Historical biogeography of Eurasian medicinal leeches. BMC Zoology, v. 1, p. 1-12, 2016. https://doi.org/10.1186/s40850-016-0002-x

Salvini-Plawen, L. V. What is convergent/homoplastic in Pogonophora? Journal of Zoological Systematics and Evolutionary Research, v. 38, p.133-147, 2000. https://doi.org/10.1046/j.1439-0469.2000.383143.x

Schulze, A. Phylogeny of Vestimentifera (Siboglinidae, Annelida) inferred from morphology. Zoologica Scripta, v. 32, p. 321-342, 2003. https://doi.org/10.1046/j.14636409.2003.00119.x

Scotlan, R. W.; Olmstead, R. G.; Bennett, J. R. Phylogeny reconstruction: The role of morphology. Systematic Biology, v. 54, p. 539-548, 2003.

Siewing, R. Thoughts about the phylogenetic: Systematic position of Pogonophora. Zeitschrit für Zoologische Systematik und Evolutionsforchung, v. 12, p. 127-138, 1975.

Smart, T. I.; von Dassow, G. Unusual development of the mitraria larva in the Polychaete Owenia collaris. The Biological Bulletin, v. 217, p. 253-268, 2009. https://doi.org/ 10.1086/bblv217n3p253

Smith, P. R.; Ruppert, E. E.; Gardiner, S. L. A deuterostome-like nephridium in the mitraria larva of Owenia fusiformis (Polychaeta, Annelida). The Biological Bulletin, v. 172, p. 315-323, 1987. https://doi.org/10.2307/1541711

Southward, E. C. Fine structure and phylogeny of the Pogonophora. Symposia of the Zoological Society of London, v. 36, p. 235-251, 1975.

Southward, E. C.; Andersen, A. C.; Hourdez, S. Lamellibrachia anaximandri n. sp., a new vestimentiferan tubeworm (Annelida) from the Mediterranean, with notes on frenulate tubeworms from the same habitat. Zoosystema, v.33, p.245-279, 2011. https://doi.org/10.5252/z2011n3a1

Southward, E.C. Development of Perviata and Vestimentifera (Pogonophora). Hydrobiologia, v. 402, p. 185-202, 1999. https://doi.org/10.1023/A:1003796626851

Steiner, T. M.; Amaral, A. C. Z. Two new species of Marphysa Quatrefages, 1865 (Eunicidae, Polychaeta) from intertidal sandy beaches of the São Sebastião Channel, State of São Paulo (Brazil). Bulletin of Marine Science, v. 67, p. 479-490, 2000. https://doi.org/ 10.11646/zootaxa.4377.2.3

Storch, V.; Welsch, U. Über den Bau und Entstehung der Mantelrandstacheln von Lingula unguis L. (Brachiopoda). Zeitschrift für Wissenschaftliche Zoologie, v. 183, n. 3/4, p. 181-189, 1972. 
Struck, T. H. Direction of evolution within Annelida and the definition of Pleistoannelida. Journal of Zoological Systematics and Evolutionary Research, v. 49, p. 340-345, 2011. https://doi.org/10.1111/j.1439-0469.2011.00640.x

Struck, T. H.; Paul, C.; Hill, N.; Hartmann, S.; Hoesel, C.; Kube, M.; Lieb, B.; Meyer, A.; Tiedemann, R.; Purschke, G.; Bleidorn, B. Phylogenomic analyses unravel annelid evolution. Nature, v. 471, p. 95-98, 2011. https://doi.org/10.1038/nature09864

Sweeney, L. B.; Luo, L. Fore brain: A hint of the ancestral cortex. Cell, v. 142, no. 5, p. 679-681, 2010. https://doi.org/10.1016/j.cell.2010.08.024

Szucsich, N.; Wirkner, C. S. Homology: A synthetic concept of evolutionary robustness of patterns. Zoologica Scripta, v. 36, p. 281-289, 2007. https://doi.org/10.1111/j.14636409.2007.00275.x

Tautz, D. Segmentation. Developmental Cell, v. 7, p. 301-312, 2004. https://doi.org/ 10.1016/j.devcel.2004.08.008

Temereva, E. N. New phoronid species Phoronopsis malakhovi (Lophophorata, Phoronida) from the South China Sea. Zoologichesckii Zhurnal, v. 79, p. 1088-1093, 2000.

Tessemar-Raible, K.; Raible, F.; Christodoulou, F.; Guy, K.; Rembold, M.; Hausen, H.; Arendt, D. Conserved sensory-neurosecretory cell types in annelid and fish forebrain: Insights into hypothalamus evolution. Cell, v. 129, p.1389-1400, 2007. https://doi.org/10.1016/ j.cell.2007.04.041

Tomer, R.; Denes, A. S.; Tissamar-Raible, K.; Arendt, D. Profiling by image registration reveals common origin of annelids mushroom bodies and vertebrate pallium. Cell, v. 142, p. 800-809, 2010. https://doi.org/10.1016/j.cell.2010.07.04.041

Wägele, J. W. Foundations of Phylogenetic Systematics (erweiterte und übersetzte Auflage des Buches von 2000). 2005.

Wägele, J. W. Hennig's Phylogenetic Systematics brought up to date. In: Williams, D. M.; Forey, P. L. (Eds). Milestones in systematics. London: CRC Press, 2004. (The Systematics Association, Special Volume Series, 67). p. 101-125.

Wagner, G. P. The character concept in evolutionary Biology. San Diego: Academic Press, 2001.

Walton, L. B. The polychaete ancestry of the insects. The American Naturalist, v. 61, no. 674, p. 226-250, 1927.

Weigert, A.; Helm, C.; Meyer, M.; Nickel, B.; Arendt, D.; Hausdorf, B.; Santos, S. R.; Halanych, K.; Purschke, G.; Bleidorn, C. Illuminating the base of the annelid tree using transcriptomics. Molecular Phylogenetics and Evolution, v. 31, p. 1391-1401, 2014. https://doi.org/10.1093/molbev/msu080

Westheide, W. The direction of evolution within the Polychaeta. Journal of Natural History, v. 31, no. 1, p. 1-15, 1997. https://doi.org/10.1080/00222939700770011

Westheide, W.; McHugh, D.; Purschke, G.; Rouse, G. Systematization of the Annelida: Different approaches. Hydrobiologia, v. 402, p. 291-307, 1999. https://doi.org/10.1023/ A:1003713230485

Wheeler, Q. D. Losing the plot: DNA "barcodes" and taxonomy. Cladistics, v. 21, p. 405-407, 2005. https://doi.org/10.1111/j.1096-0031.2005.00075.x

Wiley, E. O. Phylogenetics: The theory and practice of phylogentic systematics. New York: John Wiley \& Sons, 1981. 
Wiley, E. 0.; Lieberman, B. S. Phylogenetics: Theory and practice of phylogenetic systematic. 2. ed. New York: Wiley-Blackwell, John Wiley \& Sons, 2011.

Wilkinson, M. A comparison of two methods of character construction. Cladistics, v. 11, p. 297-308, 1995. https://doi.org/10.1111/j.1096-0031.1995.tb00091.x

Williams, D. M. Homologues and homology, phenetics and cladistics: 150 years of progress. In: Williams, D. M.; Forey, P. L. (Eds.). Milestones in systematics. London: CRC Press, 2004. (The Systematics Association, Special Volume Series, 67). p. 191-124.

Williams, D. M.; Ebach, M. C. Confusing homologs as homologies: A reply to "On homology". Cladistics, v. 28, p. 223-224, 2012. https://doi.org/10.1093/sysbio/syw094

Williams, D. M.; Ebach, M. C. Drowning by numbers: Rereading Nelson's "Nullius in Verba". The Botanical Review, v. 71, p. 415-447, 2005.

Winchell, C. J.; Sullivan, J.; Cameron, C. B.; Swalla, B. J.; Mallatt, J. Evaluating hypotheses of deuterostome phylogeny and chordate evolution with new LSU and SSU ribosomal DNA data. Molecular Phylogenetics and Evolution, v. 19, p. 762-776, 2002. https://doi.org/ 10.1093/oxfordjournals.molbev.a004134

Zeppelini, D. Phylogeny of Arrhopalites s.l. (Collembola: Symphypleona: Arrhopalitidae): Testing the monophyly of the recently erected genera Arrhopalites s.s. and Pygmarrhopalites. Invertebrate Systematics, v. 25, no. 2, p.91-105, 2011. https://doi.org/10.1071/IS10044

Zeppelini, D. Relações filogenéticas do gênero Arrhopalites (Collembola: Symphypleona: Arrhopalitidae). São Paulo: Universidade de São Paulo, 2001. (Doctorat thesis).

License information: This is an open-access article distributed under the terms of the Creative Commons Attribution License, which permits unrestricted use, distribution, and reproduction in any medium, provided the original work is properly cited. 